\title{
Yenilenen İlköğretim Matematik Öğretmenliği Lisans Programı İle İlgili Öğretim Elemanlarının Görüşleri*
}

\section{Nihal DEMIR** Elif ERTEM AKBAŞ*** Mustafa GÖK****}

Öz: Bu çalışmanın amacı, 2018-2019 eğitim-öğretim yılı itibariyle uygulanmaya başlanan ilköğretim matematik öğretmenliği lisans programının öğretim elemanlarının görüşleri doğrultusunda değerlendirilmesidir. Nitel araştırma yaklaşımının benimsendiği ve bütüncül tek durum çalışması deseni ile tasarlanan çalışmanın katılımcılarını, Doğu Anadolu Bölgesi’nde bir devlet üniversitesinin matematik eğitimi anabilim dalında görev yapan 12 öğretim elemanı oluşturmaktadır. Çalışmada veri toplama aracı olarak araştırmacılar tarafından geliştirilen yarı yapılandırılmış görüşme formu kullanılmış ve verilerin analizinde betimsel analiz tekniği kullanılmıştır. Elde edilen bulgular; derslerle ilgili görüşler, yaşanan/yaşanabilecek sorunlarla ilgili görüşler ve programın yeterlilikleri ile ilgili görüşler temaları altında sunulmuştur. $\mathrm{Bu}$ doğrultuda ulaşılan sonuçlar: Yenilenen programda kapatılan derslerle ilgili zıt görüşlerin var olduğu; yeni açılan derslerin, seçmeli derslerin ve derslerin sınıf düzeyine uygunluğunun genel olarak olumlu görüldüğü; derslerin kredilerinin ve içeriklerinin alan bilgisi dersleri açısından olumsuz görüldüğ̈̈; kurumsal boyutta, öğrenci boyutunda ve materyal boyutunda birçok sorunun yaşandığı/yaşanabileceği; programın öğretmenlik mesleği açısından yeterli bulunduğu; katılımcıların çoğu tarafından teknolojinin eğitime entegrasyonu ile matematik bilimini öğrenebilme ve öğretebilme açısından programın bazı eksikleri olduğu yönündedir. $\mathrm{Bu}$ bağlamda özellikle yenilenen programın alan bilgisinden ziyade alan eğitimine daha çok odaklandığı belirlenmiştir.

Anahtar Kelimeler: Öğretmen yetiştirme, İlköğretim matematik öğretmenliği lisans programı, Program değişikliği, Öğretim elemanları.

\footnotetext{
* Bu araştırma için Van Yüzüncü Yıl Üniversitesi Sosyal ve Beşeri Bilimleri Etik Kurulu Başkanlığından (09/10/2020 tarih ve 2020/10-06 sayıl1) etik izin alınmıştır.

** İlköğretim Matematik Öğretmeni. Milli Eğitim Bakanlı̆̆ı [MEB], Hürriyet Ortaokulu, Email:nihalldemir55@gmail.com Orcid No: 0000-0002-2178-6546.

*** Dr. Öğr. Ü. Van Yüzüncü Y11 Üniversitesi, Eğitim Fakültesi, Email:elifertem@yyu.edu.tr Orcid No: 0000-0002-40041697.

***** Dr. Öğr. Ü. Van Yüzüncü Y1l Üniversitesi, Eğitim Fakültesi, Email:mustafagok@yyu.edu.tr Orcid No: 0000-0001-93494078.
}

\begin{tabular}{lll}
\hline Gönderim:01.09.2020 Kabul:04.12.2020 & Yayın:15.01.2021
\end{tabular} 


\title{
The Views of Lecturers about the Renewed Elementary Mathematics Teacher
}

\section{Undergraduate Program Views}

\begin{abstract}
The aim of this study is to evaluate the elementary mathematics teacher undergraduate program, which started to be implemented as of the 2018-2019 academic year, in line with the opinions of the lecturers. The participants of the study, in which a qualitative research approach was adopted and designed with a holistic single case study design, are 12 lecturers working in the department of mathematics education at a state university in the Eastern Anatolia Region. In the study, a semi-structured interview form developed by the researchers was used as the data collection tool, and the descriptive analysis technique was used in the analysis of the data. The findings were presented under the themes of opinions about the lessons, views about the problems that were / may be experienced and opinions about the program's competencies. The results reached in this direction: There are opposite views about the courses closed in the renewed program; The appropriateness of newly opened courses, elective courses and courses to the grade level is generally considered positive; The credits and contents of the courses are seen negatively in terms of field knowledge courses; that many problems in institutional, student and material dimensions are experienced / can be experienced; the program is found sufficient in terms of the teaching profession; Most of the participants indicate that the program has some deficiencies in terms of the integration of technology into education and the ability to learn and teach mathematics. In this context, it was determined that the renewed program focuses more on field education rather than field knowledge.
\end{abstract}

Keywords: Teacher training, Elementary mathematics teacher undergraduate program, Program change, Lecturers.

\section{Giriş}

Ülkelerin gelişimi ve ilerlemesinde öğretmenlerin anahtar bir role sahip olduğu söylenebilir. Bu nedenle birçok gelişmiş ülkenin öncelikli amaçlarında nitelikli öğretmen yetiştirme yer almakta ve öğretmen eğitimi programları bu amaca yönelik en önemli unsurlardan biri olarak görülmektedir (Tan Şişman, 2017). Bu farkındalığın bir sonucu olarak ülkemizde, cumhuriyetin ilk yıllarında öğretmenlik mesleği bir uzmanlık alanı olarak belirtilmiştir (Üstüner, 2004). 1923-1981 yılları arasında öğretmen yetiştiren kurumlarda birçok farklı model denenmiştir (Yükseköğretim Kurumu [YÖK], 2017). Bu dönemin akabinde ilk kez 
1982 yılında eğitim fakülteleri açılarak öğretmen yetiştiren kurumlar dört yıllık lisans programı ile üniversitelere bağlanmıştır (Bilir, 2011). Bu programların en önemlilerinden biri matematik eğitimidir.

1982 yılı itibariyle Eğitim Fakültesi Fen Eğitimi Bölümü içerisinde yer alan matematik eğitimi, 1994 yılına gelindiğinde ayrı bir bölüm olmuştur (YÖK, 2017). Matematik eğitimi ilk kez 1997'de ilköğretim ve ortaöğretim olarak ayrılmış; ancak bu fiili ayrılma ile başlayan düzey bazında uzmanlaşma adımı birçok değişkenin hesaba katılmaması nedeniyle bölümlerde okutulan dersler ve bu derslerin içerikleriyle ilgili tartışmalara neden olmuştur (YÖK, 2017).

$\mathrm{Bu}$ tartışmaların özellikle eğitim fakültelerinin fen edebiyat fakültelerinin farklı bir yansıması olarak devam etmesinden kaynaklandığı söylenebilir. Nitekim Kartal (2011), 19821997 yılları arasında uygulanan programlarda eğitim fakültelerinin temel amacından uzak bir şekilde örtülü birer fen edebiyat fakülteleri haline geldiğini belirtmiştir. Aynı yayında eğitim fakülteleriyle ilgili 1997 ve 2009 yıllarında çeşitli düzenlemeler yapıldığı belirtilmiş ancak bu algının değişmediği vurgulanmıştır. Bu iddianın temelini, eğitim fakültelerinde okutulan derslerin yarıdan fazlasının fen fakültelerinde okutulan derslerle örtüşmesinin (YÖK, 2006) oluşturduğu belirtilebilir. Diğer bir ifadeyle alan eğitimi derslerine çok az yer verilmesinin bu durumu ortaya çıkardığı söylenebilir. Alan eğitimi derslerinin yetersizliği ve zamanla ortaya çıkan yeni parametreler programın yeniden gözden geçirilmesini zorunlu kılmıştır.

Grossman ve Sands (2008), Türkiye'de öğretmen yetiştiren programlarda pek çok şey başarılmış olsa da bunların henüz yeterli olmadığını belirtmiştir. Öğretmen yetiştirme programı toplumdaki değişen ihtiyaç ve talepler, mevcut programla ilgili yapılan araştırma sonuçları odağında yeniden düzenlenmiştir (YÖK, 2018). Bu durumun gerekçelerinden birini Kızılçaoğlu (2006), öğretmenlik bilgisi ve uygulama derslerine yeterince yer verilmemesi şeklinde açıklamıştır. Program içeriklerinin başka ülkelerle karşılaştırıldığı bir çalışmada da Finlandiya'nın öğretmen yetiştirme programında uygulama derslerinin Türkiye'deki programa göre daha yoğun olduğu görülmüştür (Aras ve Sözen, 2012). Bu durumu kanıtlar şekilde Eraslan (2009), matematik öğretmen adaylarının lisans eğitiminde aldıkları matematik dersleri ile ortaokul matematiğini ilişkilendiremediklerini ve öğrendiklerini uygulamak için yeterli imkânı bulamadıklarını ifade etmiştir. Başka bir çalışmada da öğretmen adaylarının çoğunun dersleri teorik bulduğu ve uygulamalı derslerin arttırılması gerektiğini düşündükleri belirtilmiştir (Gökçek ve Kaya, 2017). Program değişikliklerinin hem zorluk hem de firsat yaratabilme (Johnson, Nebesniak ve Rupnow, 2019) potansiyeli teori-pratik arasındaki boşluğu 
kapatacak şekilde firsata dönüştürülebilir. Teoride öğretildiği ifade edilen bilginin pratikte gözlenememesi sonucunda, 2018 yılında öğretmen yetiştiren programlarda geniş ölçekli bir değişiklik gerçekleştirilmiştir. Bu güncellemede bazı derslerin okutulduğu sınıf düzeyleri ve içeriklerinde değişikliğe gidilmiş, bazı dersler kaldırılmış ve az da olsa bir takım yeni dersler programa dâhil edilmiştir (YÖK, 2018). Diğer taraftan yapılan güncelleme sonucunda kaldırılan-eklenen dersler ile bu derslerin kredileri ve içerikleri düşünüldüğünde bu durumun olumsuz etkileri olabileceği de düşünülmektedir (Özdemir, 2018).

Bu doğrultuda bu çalışmada, ülkemizde ilk kez 1998'de kurulan ve şu an birçok üniversitede eğitim fakülteleri içerisinde yer alan ilköğretim matematik öğretmenliği programı değişikliğine odaklanılmıştır. Bunun nedeni, programın ilk yıllarında alan bilgisi içeriklerinin fen fakültelerinin bir dönüşümünü yansıtması ve alan bilgisinin eğitimine çok sınırlı düzeyde yer verilmesidir. Ayrıca 2018 yılı değişikliği ile birlikte bunun tersi bir anlayışın programın derslerinde ve içeriklerinde egemen olması çalışmada ilköğretim matematik öğretmenliği programına odaklanılmasına yol açmıştır. Bu bağlamda çalışmada ilköğretim matematik öğretim programlarının 2018 öncesi ve sonrası karşılaştırılacaktır. Bu sayede alan bilgisi ve alan bilgisi eğitimi dersleri bağlamında programdaki değişim daha net ortaya koyulacaktır. Böylece çalışma bağlamında bu durum ile ilgili öğretim elemanlarının düşünceleri açık ve detaylı bir şekilde analiz edilebilecek ve daha tutarlı bir zeminde tartışılabilecektir.

\section{8 Öncesi ve 2018 Sonrası İlköğretim Matematik Öğretmenliği Lisans Programı}

İlköğretim matematik öğretmenliği lisans programı 2018 öncesi ve sonrası alan bilgisi ve alan eğitimi dersleri ve kredileri Tablo 1'de karşılaştırmalı gösterilmiştir. 2018 değişikliğinde alan bilgisi ve alan eğitimi derslerinin tamamının alan eğitimi içerisinde değerlendirildiği görülmektedir. Bu çalışmada bu anlamda bir ayrıma gidilmiştir. Örneğin 2018 değişikliği sonrası ilköğretim matematik öğretmenliği lisans programında soyut matematik dersi alan eğitimi dersi çerçevesinde değerlendirilmiştir. Ancak bu ders daha çok alan bilgisini yansıttığı gerekçesiyle bu çalışmada alan bilgisi bağlamında değerlendirilmiştir.

Tablo 1. 2018 Öncesi ve Sonrası İlköğretim Matematik Öğretmenliği Lisans Programı Alan Bilgisi (AB) ve Alan Eğitimi (AE) Dersleri ve Kredileri (T:Teorik, U:Uygulama)

\begin{tabular}{lllllll}
\hline Yariyl & $\mathbf{2 0 1 8}$ öncesi & $\mathbf{T}$ & $\mathbf{U}$ & $\mathbf{2 0 1 8}$ sonrasi & T & $\mathbf{U}$ \\
\hline 1. & Genel Matematik (AB) & 4 & 2 & Matematiğin Temelleri 1 (AE) & 2 & 0 \\
& & & & Analiz 1 (AB) & 2 & 0 \\
& & & & Matematik Tarihi & 2 & 0 \\
2. & & 3 & 0 & Matematiği Temelleri 2 (AE) & 2 & 0 \\
& Soyut Matematik (AB) & 3 & 0 & Analiz 2 (AB) & 2 & 0 \\
& Geometri (AE) & & & Soyut Matematik (AB) & 2 & 0 \\
3. & Analiz I (AB) & 4 & 2 & Matematik Öğrenme ve Öğretim Yak. (AE) & 2 & 0 \\
\hline
\end{tabular}




\begin{tabular}{|c|c|c|c|c|c|c|}
\hline & Lineer Cebir I (AB) & 3 & 0 & Lineer Cebir 1 (AB) & 2 & 0 \\
\hline & Fizik I (AB) & 4 & 0 & Analitik Geometri (AB) & 2 & 0 \\
\hline & Seçmeli I & 2 & 0 & Analiz 3 AB) & 2 & 0 \\
\hline & & & & Seçmeli 1 & 2 & 0 \\
\hline \multirow{5}{*}{4.} & Analiz II (AB) & 4 & 2 & Ortaokul Matematik Öğretim Prog. (AE) & 2 & 0 \\
\hline & Lineer Cebir II (AB) & 3 & 0 & Lineer Cebir 2 (AB) & 2 & 0 \\
\hline & Fizik II (AB) & 4 & 0 & Algoritma ve Programlama & 2 & 0 \\
\hline & & & & Olasılık (AB) & 2 & 0 \\
\hline & & & & Seçmeli 2 & 2 & 0 \\
\hline \multirow[t]{5}{*}{5.} & Analiz III (AB) & 3 & 0 & Sayıların Öğretimi (AE) & 3 & 0 \\
\hline & Analitik Geometri I (AB) & 3 & 0 & Geometri ve Ölçme Öğretimi (AE) & 3 & 0 \\
\hline & İstatistik ve Olasılık I (AB) & 2 & 2 & İstatistik (AB) & 2 & 0 \\
\hline & Cebire Giriş (AB) & 3 & 0 & Cebir (AB) & 2 & 0 \\
\hline & Özel Öğretim Yön. I (AE) & 2 & 2 & Seçmeli 3 & 2 & 0 \\
\hline \multirow[t]{4}{*}{6.} & Diferansiyel Denklemler (AB) & 4 & 0 & Cebir Öğretimi (AE) & 3 & 0 \\
\hline & Analitik Geometri II (AB) & 3 & 0 & Olasılık ve İstatistik Öğretimi (AE) & 3 & 0 \\
\hline & İstatistik ve Olasılık II (AB) & 2 & 2 & Matematik Öğretiminde İlişkilendirme(AE) & 3 & 0 \\
\hline & Özel Öğretim Yön. II (AE) & 2 & 2 & Seçmeli 4 & 2 & 0 \\
\hline \multirow[t]{4}{*}{7.} & Elementer Sayı Kuramı (AB) & 3 & 0 & Matematikte Problem Çözme (AE) & 2 & 0 \\
\hline & Seçmeli II & 3 & 0 & Matematik Öğretiminde KavramYanıl.(AE) & 2 & 0 \\
\hline & Matematik Tarihi & 2 & 0 & Mantıksal Akıl Yürütme (AE) & 2 & 0 \\
\hline & & & & Seçmeli 5 & 2 & 0 \\
\hline \multirow[t]{3}{*}{8.} & Matematik Felsefesi & 2 & 0 & Matematik Felsefesi & 2 & 0 \\
\hline & & & & Matematik Öğretiminde Modelleme (AE) & 2 & 0 \\
\hline & & & & Seçmeli 6 & 2 & 0 \\
\hline Toplam & 23 ders & 64 & 14 & 32 ders & 69 & 0 \\
\hline
\end{tabular}

Tablo 1'den 2018 değişikliği ile birlikte alan bilgisi derslerinin bazılarının kaldırıldığ1 ve birçok dersin kredilerinin azaltıldığı görülmektedir. Bu değişiklik alan eğitimi dersleri bağlamında düşünüldüğünde köklü bir reform niteliği taşıdığı söylenebilir. 2018 değişikliği öncesinde çok sınırlı sayıda alan eğitimi dersinin yer aldığı programda, 2018 değişikliği ile birlikte birçok alan eğitimi dersi yer almıştır. Ayrıca yarıyıl bazında verilen alan ve alan eğitimi derslerinin yoğunluğunun arttığı da dikkat çekicidir. Sonuç olarak, ilköğretim matematik öğretmenliği programında 2018 değişikliği ile birlikte programda alan bilgisi ve alan eğitimi dersleri ile ilgili bakış açısının değiştiği anlaşılmaktadır. Bu durum program geliştiricilerin neyin öğretilmesi gerektiği yaklaşımından öğretim ve öğrenmenin nasıl yapılması gerektiği yaklaşımına doğru kaydığını işaret etmektedir (Marchese, 2006). Bu bağlamda yeni programda alan eğitimi dersleri yoğun bir şekilde yer almaktadır. Bu bakış açısıyla ilköğretim matematik öğretmenlerinin sahip olması gereken bilgi ile ilgili değişiklik yapılmak istendiği belirtilebilir.

Öğretmenlerin hangi matematik bilgisine sahip olması gerektiği ve bunun nasıl elde edileceği ile ilgili, alan dersleri ile öğretecekleri matematik dersleri arasında ilişki kurmalarını sağlayacak derslerin tasarlanması önerilmektedir (Conference Board of the Mathematical Sciences [CBMS], 2001). Bu doğrultuda matematik öğretimine fayda sağlayacak öğretmen bilgisinin, matematik içeriği ile pedagojinin birleşimi olan ‘öğretim için matematik’ olduğu 
ifade edilmiştir (Ball, Hill ve Bass, 2005). Matematik öğretimi için, matematik alan bilgisinin gerekli olduğu (Gök, 2016) ama alan öğretimini gerçekleştirmede yeterli olmadığı belirtilmiştir (Türnüklü, 2005). Bunu destekleyecek şekilde ilköğretim matematik öğretmeni adayları, öğretici vasıfları daha ön planda olduğundan, yapacakları öğretime yönelik lisans eğitimi almak istediklerini belirtmişlerdir (Aksu, 2016). Sonuç olarak, gerçekleştirilen bu değişikliğin öğretmen bilgisini etkileyeceği belirtilebilir. Ancak bunun ne ölçüde fayda sağlayacağı ya da memnuniyet getireceği değişik bakış açılarına sahip bireyler açısından tartışılmalıdır. $\mathrm{Bu}$ anlamda değişikliği uygulamakla yükümlü olan öğretim elemanlarının değişikliğe ilişkin bakış açılarının ne olduğu bu çalışmanın motivasyonunu oluşturmaktadır.

Literatür incelendiğinde eğitim fakültesi lisans programlarının 2018 yılında yenilenmesi ile Türkçe öğretmenliği, okul öncesi öğretmenliği, biyoloji öğretmenliği ve sınıf öğretmenliği lisans programları üzerine akademik çalışmalar yapılmıştır (Alver ve Aydın, 2019; Bartan, 2019; Karakaya, Adıgüzel, Çimen ve Yılmaz, 2020; Kılıç Özmen, 2019). İlköğretim matematik öğretmenliği programında alan bilgisi ve alan eğitimi perspektifinde büyük bir değişim yaşanmasına rağmen bu bağlamda herhangi bir çalışma olmadığı görülmüştür. Ayrıca öğretim elemanlarının bu değişime ilişsin bakış açılarını yansıtan çalışmalar, programda alan bilgisi ve alan eğitiminin egemen olmasına ilişkin tartışmalarda odak noktası olması yönüyle önemlidir. Alan ve alan eğitimcilerinin programa bakış açılarının farklı olduğu (Appelbaum, Friedler, Ortiz ve Wolff, 2009) bilinmektedir. Program değişimlerinin birçok değişkeni içermesinden dolayı karmaşık bir doğası olduğu ve bu yüzden bireylerin ilgili değişimleri kısa sürede kabul etmeyebilecekleri vurgulanmaktadır (Berestova, Lazareva ve Leontyev, 2020). Bu doğrultuda bu çalışmanın amacı, 2018-2019 eğitim-öğretim yılı itibariyle uygulanmaya başlanan ilköğretim matematik öğretmenliği lisans programının, öğretim elemanlarının görüşleri doğrultusunda değerlendirilmesidir. Bu amaca yönelik şu sorulara cevap aranmaktadır: 2018 yılında yenilenen İlköğretim matematik öğretmenliği programına (IMOÖP) yönelik öğretim elemanlarının;

1)Kapatılan dersler, yeni açılan dersler, seçmeli dersler, derslerin kredileri, derslerin içerikleri ve derslerin sınıf düzeyine uygunluğu ile ilgili görüşleri nelerdir?

2)Kurumsal boyutta, öğrenci boyutunda ve materyal boyutunda yaşanan/yaşanabilecek sorunlarla ilgili görüşleri nelerdir? 
3)Öğretmenlik mesleği açısından, teknolojinin eğitime entegrasyonu açısından ve matematik bilimini öğrenebilme-öğretebilme açısından programın yeterliliği ile ilgili görüşleri nelerdir?

\section{Yöntem}

\section{Araştırmanın Deseni}

Araştırmanın amacı doğrultusunda nitel araştırma yaklaşımının benimsenmiş olduğu bu çalışma, durum çalışması (case study) olarak tasarlanmıştır. Nitel çalışmalar; katılımcıların anlayışlarının, duygu ve düşüncelerinin, gerçekçi ve bütüncül biçimde araştırılmasını sağlaması bakımından tercih edilmektedir (Yıldırım ve Şimşek, 2018). Çalışma kapsamında belli bir durum ve sürecin gerçek bir şekilde ele alınıp bütüncül karakteristikleri belirlenerek derinlemesine anlaşılması ve tartışılmasına odaklanılmıştır (Merriam, 2009). Ayrıca çalışma, durum çalışması çeşitlerinden tek bir analiz birimine odaklanan bütüncül tek durum desen çeşidine göre tasarlanmıştır (Yin, 2009). Durumun yenilenen ilköğretim matematik öğretmenliği lisans programı olması tek bir analiz birimine odaklanmayı sağlamıştır. Öğretim elemanlarının görüşlerinin ele alınması bu durumun ayrıntılı şekilde farklı bakış açıları düşünülerek incelenmesini sağlamıştır.

\section{Katılımcilar}

Çalışmaya 2019-2020 eğitim öğretim yılının güz döneminde Doğu Anadolu Bölgesi'nde bir devlet üniversitesinin matematik eğitimi anabilim dalında görev yapan 12 (3 kadın, 9 erkek) öğretim elemanı katılmıştır. İlgili üniversitenin seçilmesinde ulaşılabilir örnekleme yöntemi kullanılmışken, bu üniversitedeki öğretim elemanlarının seçiminde amaçsal örnekleme yöntemi kullanılmıştır. Amaçlı örnekleme, ele alınan durumun derinlemesine açıklanabilmesine olanak sağlayacak bireylerin seçilmesinin önemli olduğu durumlarda kullanılmaktadır (Büyüköztürk, Çakmak Kılıç, Akgün, Karadeniz ve Demirel, 2008). Çalışmanın katılımcılarının belirlenmesinde, araştırmanın amacı doğrultusunda amaçlı örnekleme tekniklerinden biri olan ölçüt örnekleme kullanılmıştır. Çalışma grubunun ölçütlerinin belirlenmesinde öğretim elemanlarının ilköğretim matematik öğretmenliği lisans programında alan bilgisi veya alan eğitimi derslerinden en az birini veriyor olması ve uygulamaya geçen yeni İMÖP ve uygulamadan kalkan eski İMÖP hakkında bilgi sahibi olması göz önünde bulundurulmuştur. $\mathrm{Bu}$ ölçütler ile çalışma kapsamında ele alınan durumda katılımcıların düşüncelerinin bütüncül bir şekilde yansıtılması amaçlanmıştır. Ayrıca çalışma 
grubuna dahil edilen öğretim elemanlarının gönüllü katılımı sağlanmış olup K1, K2, .., K12 şeklinde kodlanan katılımcılara ilişkin demografik bilgiler Tablo 2'de sunulmuştur.

Tablo 2. Çalışma Grubunun Demografik Özellikleri

\begin{tabular}{llllll} 
Katılıme & Cinsiyet & Yaş & Öğrenim & Lisans & Unvan \\
\hline K1 & Kadın & 34 & Doktora & Eğitim F. & Dr. Öğr. Ü. \\
K2 & Erkek & 29 & Doktora & Fen F. & Dr. Öğr. Ü. \\
$\mathbf{K 3}$ & Erkek & 44 & Doktora & Fen F. & Dr. Öğr. Ü. \\
$\mathbf{K} 4$ & Kadın & 34 & Doktora & Eğitim F. & Doç. Dr. \\
$\mathbf{K 5}$ & Erkek & 40 & Y.Lisans & Fen F. & Öğr. Gör. \\
$\mathbf{K 6}$ & Erkek & 50 & Doktora & Fen F. & Dr. Öğr. Ü. \\
$\mathbf{K 7}$ & Erkek & 48 & Y.Lisans & Fen F. & Öğr. Gör. \\
$\mathbf{K 8}$ & Kadın & 32 & Doktora & Fen F. & Dr. Öğr. Ü. \\
$\mathbf{K 9}$ & Erkek & 44 & Doktora & Eğitim F. & Doç. Dr. \\
$\mathbf{K 1 0}$ & Erkek & 39 & Doktora & Eğitim F. & Dr. Öğr. Ü. \\
$\mathbf{K 1 1}$ & Erkek & 39 & Doktora & Eğitim F. & Doç. Dr. \\
$\mathbf{K 1 2}$ & Erkek & 54 & Doktora & Fen F. & Prof. Dr.
\end{tabular}

\section{Veri Toplama Aracı}

Araştırmada veri toplama aracı olarak araştırmacılar tarafından geliştirilen yarı yapılandırılmış görüşme formu kullanılmıştır. Görüşme formunun geliştirilmesi sürecinde literatür taranarak benzer çalışmalarda sorulan sorular incelenmiş (Demircan, 2010; Özdemir, 2018; Taş, Kunduroğlu Akar ve Kıroğlu, 2017) ve bu çalışmanın amacına uygun olacak şekilde araştırmacılar tarafından program değişikliği ile ilgili sorular oluşturulmuştur. Sonrasında dil, alan bilgisi ve alan eğitimi bağlamında alınan uzman görüşleri doğrultusunda görüşme soruları daha açık ve anlaşılır olacak şekilde düzenlenmiştir. Bu sürecin sonunda 10 adet demografik sorunun ve 8 adet program değiş̧ikliği ile ilgili sorunun yer aldığı görüşme formu hazırlanmıştır. Katılımcıların hepsiyle yüz yüze görüşülmüş olup katılımcıların da izniyle görüşmeler sırasında ses kaydı alınmıştır. Görüşmelerin yapılması, yani veri toplama süreci 1 hafta sürmüştür. Görüşme sorularından bazıları şu şekildedir:

- IMÖP değişikliği ile ilgili eksik kaldığını düşündüğünüz noktalar nelerdir?

- IMÖP değişikliğini öğretmenlik mesleği açısından nasıl değerlendiriyorsunuz? 
- İMÖP değişikliğini teknolojinin eğitime entegrasyonu açısından değerlendirdiğinizde yeterli olduğunu düşünüyor musunuz? Neden?

\section{Verilerin Analizi}

Nitel araştırmalarda veri toplama tekniklerinden elde edilen veriler düzenlenip kategorilere ayrılır, temalar keşfedilir ve elde edilen sonuçlar raporlaştırılır (Özdemir, 2010). Dolayısıyla bu çalışma kapsamında yapılan görüşmelerden elde edilen verilerin analizinde ilk olarak ses kayıt cihazı ile kayıt altına alınan yarı yapılandırılmış görüşmeler tekrar tekrar dinleme yoluyla transkript edilmiş ve betimsel analiz yardımıyla çözümlenmiştir. Betimsel analiz, nitel veri toplama araçları ile elde edilen verilerin önceden belirlenen temalara göre özetlendiği ve yorumlandığı bir analiz tekniğidir (Özdemir, 2010). Yapılan analizler sonucunda elde edilen verilerin temalaştırılması araştırma soruları temelinde yapılmıştır. Katılımcılar tarafından verilen cevaplardan yola çıkılarak kodlar ve kategoriler oluşturulmuştur. Araştırmacılar tarafından yapılan bu kodlamalara, kodlamaya rehberlik edecek bir kavramsal yapı olmadığı için tümevarımcı bir analizle ulaşılmıştır (Strauss ve Corbin, 1990). Tümevarımcı analizde, kodlama yoluyla verilerin altında yatan kavramların ve bu kavramlar arasındaki ilişkilerin ortaya çıkarılması söz konusudur (Karataş, 2015). Bu çalışmada kullanılan kod ve temalara ilişkin doğrudan alıntılarla katılımeı görüşlerine yer verilerek elde edilen bulgular okuyucuya detaylı şekilde sunulmuştur. Ayrıca etik kurallar çerçevesinde öğretim elemanlarının kişisel bilgilerinin saklı tutulması amacıyla bulgular sunulurken katılımcılar K1, $\mathrm{K} 2, \ldots, \mathrm{K} 12$ şeklinde kodlanarak ifade edilmiştir.

\section{Geçerlik ve Güvenirlik}

Nitel araştırmaların verileri kendine özgüdür ve bağlamsaldır. Dolayısıyla geçerliliği test edecek kriterler iç geçerlik yerine inanılırlık, dış geçerlik yerine aktarılabilirlik, iç güvenirlik yerine tutarlılık ve dış güvenirlik yerine ise doğrulanabilirlik kavramları şeklinde düzenlenmiştir (Lincoln, Lynham ve Guba, 2011). Bu doğrultuda çalışmada öğretim elemanları ile yapılan görüşmeler ses kayıt cihazı ile kayıt altına alınmış ve derinlemesine incelenip saklanarak çalışmanın inanırlığı sağlanmıştır. Ayrıca öğretim elemanlarının cevaplarının yorumlanmasında ön yargılardan arınmaya gayret gösterilmiş ve nesnel olmaya çalışılmıştır. Aktarılabilirlik için; araştırma deseni, çalışma grubu, veri toplama aracı, verilerin toplama süreci mümkün olduğunca ayrıntılı olarak betimlenmeye çalış1lmıştır. Tutarlılık için öğretim elemanları ile yapılan görüşmelerden elde edilen verilerin analizi kısmında alanında uzman iki öğretim üyesinin görüşleri alınmış, tartışılmış ve kodlanmıştır. Kodlayıcılar arasındaki uyum, 
uyum kodlayıcı yüzde formülüne göre \%90 olarak belirlenmiştir (Miles ve Huberman, 1994). Bulgularının iç geçerliğini sağlamak amacıyla kullanılan stratejilerden birisi olan doğrulanabilirlik (Shenton, 2004; Yıldırım ve Şimşek, 2018) için katılımcı görüşlerinden bazıları doğrudan alıntılarla verilmiştir. Ayrıca analiz süreci ayrıntılı bir şekilde açıklanıp, elde edilen kod ve temalar farklı uzmanlar tarafından kontrol edilmiştir.

\section{Etik Kurul Kararı}

Van Yüzüncü Yıl Üniversitesi Sosyal ve Beşeri Bilimleri Yayın Etik Kurulu'nun, 09/10/2020 tarih ve 2020/10-06 sayılı kararı gereği çalışma açısından Sosyal ve Beşeri Etik Kuralları ve İlkeleri çerçevesinde herhangi bir sakınca olmadığına karar verilmiştir.

\section{Bulgular}

Çalışmanın bu bölümünde elde edilen verilerin betimsel analizi sonucu ulaşılan kodlar, çalışmanın amacı doğrultusunda belirlenen araştırma soruları kapsamında; derslerle ilgili görüşler, yaşanan/yaşanabilecek sorunlarla ilgili görüşler ve programın yeterlilikleri ile ilgili görüşler ana temaları altında sunulmuştur.

\section{Yenilenen İMÖP Kapsamında Yer Alan Derslerle İlgili Görüşlere Yönelik Bulgular}

Derslerle ilgili görüşler teması içerisinde öğretim elemanlarından alınan görüşler; kapatılan dersler, yeni açılan dersler, seçmeli dersler, derslerin kredileri, derslerin içerikleri ve derslerin sınıf düzeyine uygunluğu şeklinde alt temalara ayrılmıştır. Bu alt temalara ilişkin görüşlere göre kodlamalar yapılmıştır.

Kapatılan Dersler alt temasına ait öğretim elemanı görüşlerinden elde edilen verilere ilişkin kodlamalar Tablo 3'te sunulmuştur.

Tablo 3. Öğretim Elemanlarının Kapatılan Derslere İlişkin Görüşleri

\begin{tabular}{lllll}
\hline Alt Tema & Kategori & \multicolumn{1}{c}{ Kod } & Katılımcı Kodu & Frekans (f) \\
\hline & Elementer Say1 Kuram1 & Kapatılmas1 uygun & K1, K2, K10 & 3 \\
& & Kapatılmas1 uygun değil & K4, K5, K12 & 3 \\
Kapatılan & Genel Matematik & Kapatılmas1 uygun & K4, K5, K7 & 3 \\
Dersler & & Kapatılmas1 uygun değil & K1, K10 & 2 \\
& Geometri & Kapatılmas1 uygun & K7 & 1 \\
& & Kapatılmas1 uygun değil & K1, K9 & 2 \\
\hline
\end{tabular}

Tablo 3 incelendiğinde öğretim elemanlarının kapatılan benzer derslerle ilgili zıt görüşlere sahip olduğu düşünülmesine rağmen; öğretim elemanı kodları incelendiğinde K1, K4, K5 ve K10'un ( $\mathrm{f}=4$ ) kapatılan derslere ilişkin birden fazla (olumlu-olumsuz) yönde görüş bildirdiği görülmüştür. $\mathrm{Bu}$ durum ele alınan bu derslerin kapatılmasının olumlu ve olumsuz yönde yansımalarının olabileceği şeklinde yorumlanabilir. 
K1: “'Elementer Sayı Kuramı’ dersinin çok ileri düzeyde anlatılmasının çok da gerekli olduğunu düşünmüyorum ilköğretim matematik öğretmenliği okuyacak bir öğrenci için. Ama 'Geometri' dersini almadan da öğretiminin dersi alınamaz diye düşünüyorum. 'Genel Matematik' dersinin olmayışı da dikkatimi çekti, olması gerekirdi, en azından 1. sınıfta. Daha sonrasında analizlere geçişin yapılması gerektiğini düşünüyorum. "

K5: “ 'Genel Matematik' dersinin kapatılması bence iyi oldu, çünkü önceden ilkögretim matematik öğretmenliği programına gelen öğrenciler uyum içinde olsun diye bu dersler veriliyordu ama şimdi liselerde de bu dersler aktif olarak veriliyor. 'Elementer Sayı Kuramı' keşke kalkmasaydı. Bu ders bir öğretmenin her zaman ihtiyaç duyduğu bir ders ve düşünmeye yönlendiriyor."

K7: “'Genel Matematik’ dersi kapatılmış, çok da sorun olacă̆ını düşünmüyorum, analizin içerisinde rahatlıkla verilebilecek bir ders."

K1 tarafından ifade edilen görüşlere bakıldığında Genel Matematik dersinin Analiz derslerine önbilgi oluşturması bakımından kapatılmasının bazı zorluklar yaratacağını düşündüğü ve bu açıdan kapatılmasını olumsuz bulduğu görülmektedir. Bu görüşe bakıldığında yenilenen programda bazı dersler açısından ekolojik sorun (Sağlam Arslan, 2016) oluşabileceğine işaret edilmektedir. Diğer taraftan dikkat çeken bir diğer nokta da oldukça zit görüşlerin ifade edilmiş olmasıdır. Örneğin K5 tarafından Elementer Sayı Kuramı dersi bir matematik öğretmeninin bilmesi gereken dersler arasında görülürken, K1 tarafından ise tam da aynı gerekçe ile gerekli bir ders olmadığı ifade edilmiştir. Genel Matematik dersi de K1 tarafından analiz derslerine hazırbulunuşluğu sağlaması açısından gerekli bir ders olarak görülürken, K7 tarafından ise analiz dersleri içerisinde kısa zamanda verilebilecek bir ders olduğunu ifade etmektedir. Burada derslerin hiç alınmamasından ziyade başka bir dersin içinde telafisinin yapılabileceği düşüncesinin hâkim olduğu görülmektedir. Bu doğrultuda kapatılan derslerin, ön bilgileri oluşturması ve bir başka ders içerisinde kullanılması nedeniyle öğretim elemanları arasında tartışmalı bir konu olduğu düşünülmektedir.

Yeni Açılan Dersler alt temasına ait öğretim elemanı görüşlerinden elde edilen verilere ilişkin kodlamalar Tablo 4'te sunulmuştur.

Tablo 4. Öğretim Elemanlarının Yeni Açılan Derslere İlişkin Görüşleri

\begin{tabular}{lllll}
\hline Alt Tema & Kategori & Kod & Katılımcı Kodu & Frekans (f) \\
\hline Yeni Açılan Dersler & Olumlu Görüşler & $\begin{array}{l}\text { Öğretim } \\
\text { derslerinin } \\
\text { aç1lmas1 } \\
\text { olumlu }\end{array}$ & $\begin{array}{l}\text { K1, K2, K3, K4, K5, K6, K7, } \\
\text { K8, K9, K10, K11, K12 }\end{array}$ & 12 \\
\hline
\end{tabular}


Tablo 4'e bakıldığında yenilenen ilköğretim matematik öğretmenliği lisans programının öğretim süreci için yeni açılan tüm derslerin katılımcıların tamamı (f=12) tarafından olumlu yönde karşılandığı görülmektedir. Özellikle yeni açılan öğretim derslerinin öğretmen adayları için önemli ve gerekli olduğu ifade edilmiştir.

K7: “Mezun olacak öğrenciler öğretmen olacak. Bildiğini nasıl aktaracă̆ı önemlidir. Ne kadar yöntem metot biliyorsa faydasınadır. Bu bă̆lamda açılan alan eğitimi (ögretim) derslerini olumlu buluyorum.”

K11: “'Cebir' var, 'Cebir Öğretimi' var, bence çok güzel. Öğretime yönelik açılan birçok ders var. Hakkıyla verilirse ögretmenlerin kalifiye olacağına inanıyorum."

Öğretim elemanlarının görüşleri incelendiğinde genel olarak yeni açılan derslerin, teorik bilginin uygulamada gözlenebilmesi üzerinde etkili olabileceğini belirttikleri görülmüştür. Programa eklenen öğretim derslerinin içeriğine bakıldığında, alan bilgisi ile eğitimin bir arada olduğu dikkat çekmektedir. Bu bağlamda yenilenen program ile birlikte teori ile pratik bloğunun birleştirilmek istendiği ve alan eğitimine ağırlık verilmesiyle paradigmanın değiştiği belirtilebilir. Yeni açılan derslerle birlikte meydana gelen bu değişimi öğretim elemanlarının da bu bağlamda düşündüğü anlaşılmaktadır. Bu doğrultuda öğretim elemanlarının görüşleri ile öğretim derslerinin açılmasındaki amaç paralellik göstermektedir.

Seçmeli Dersler alt temasına ait öğretim elemanı görüşlerinden elde edilen verilere ilişkin kodlamalar Tablo 5'te sunulmuştur.

Tablo 5. Öğretim Elemanlarının Seçmeli Derslere İlişkin Görüşleri

\begin{tabular}{|c|c|c|c|c|}
\hline Alt Tema & Kategori & Kod & Katılımeı Kodları & $\begin{array}{l}\text { Frekans } \\
\text { (f) }\end{array}$ \\
\hline \multirow{5}{*}{$\begin{array}{l}\text { Seçmeli } \\
\text { Dersler }\end{array}$} & $\begin{array}{l}\text { Olumlu } \\
\text { Görüşler }\end{array}$ & Faydalı, güzel & $\begin{array}{l}\mathrm{K} 1, \mathrm{~K} 3, \mathrm{~K} 5, \mathrm{~K} 7, \mathrm{~K} 8 \\
\mathrm{~K} 10, \mathrm{~K} 11, \mathrm{~K} 12\end{array}$ & 8 \\
\hline & $\begin{array}{l}\text { Olumsuz } \\
\text { Görüşler }\end{array}$ & Çoğunun alan derslerine yönelik olması & K2 & 1 \\
\hline & & $\begin{array}{l}\text { Dersin öğretilmesine yönelik eksiklikler } \\
\text { (materyal/ öğretim elemanı) }\end{array}$ & K4 & 1 \\
\hline & & $\begin{array}{l}\text { Önceden zorunlu olup sonradan seçmeli olan } \\
\text { dersler }\end{array}$ & K6 & 1 \\
\hline & & $\begin{array}{l}\text { Derslerin öğretim elemanlarına dağıtılmasında } \\
\text { yaşanabilecek zorluklar }\end{array}$ & K9 & 1 \\
\hline
\end{tabular}

Tablo 5 incelendiğinde seçmeli derslere ilişkin çoğu öğretim elemanının $(\mathrm{f}=8)$ olumlu yönde görüş bildirdiği görülmektedir. Diğer taraftan bazı öğretim elemanları $(\mathrm{f}=4)$ tarafından seçmeli derslerle ilgili birtakım sorunların olduğu belirtilmiştir. 
K2: “Alan bilgisine yönelik olan dersleri ben çok iyi karşılamadım. Çünkü öğretmen adaylarının mezun olduktan sonra ilgilendikleri alanla çok büyük bir ilgisi olmadı̆̆ını düşünüyorum. Matematiği günlük hayatla ilişkilendirecek derslere, özellikle teknoloji destekli matematik öğretimine yönelik çok fazla ders olmadığını görüyorum.”

K9: "Seçmeli derslerde esneklik sağlanması (çoğunun alan dersleri olması) bölümdeki derslerin dă̆ıtımında sıkıntı yaşayacă̆ımız anlamına gelmektedir."

K12: "Bir programı tamamlamak adına uygun bir ortam. Burada belli bir kisitlama yapılmamış. Programı daha zenginleştirebilir, esnekliği săglar, faydalı olmuş. Eksik hissedilen yönlere göre ögrenciler yönlendirilerek eksikler burada tamamlanabilir.",

Öğretim elemanı görüşleri incelendiğinde K2'nin seçmeli derslerin çoğunun alan derslerine yönelik olmasının yeterli çeşitliliği sağlayamayacağını, bundan dolayı seçmeli derslerde uygulamalı derslerin ve teknolojiye yönelik derslerin olması gerektiğini belirttiği görülmektedir. Bu bakımdan seçmeli derslerin meslekte kullanılabilecek şekilde, teoriden ziyade pratiğe ağırlık veren derslerden oluşması önerilmektedir. K9 ve K12 tarafından seçmeli derslerin esnekliği sağlaması bakımından hemfikir oldukları görülmektedir. Ancak K9 tarafından seçmeli derslerin bu özelliğgi nedeniyle öğretim elemanlarına dağıtılmasının zorlaşacağ1, K12 tarafindan ise bu özelliği sayesinde öğrencilerin eksik kalan bilgilerinin tamamlanabileceği düşünülmüştür. Bu görüşlerden hareketle aynı sebep gösterilerek hem olumlu hem de olumsuz sonuçların görülebileceğine ilişkin bir zıtllğın gözlendiği belirtilebilir. $\mathrm{Bu}$ doğrultuda seçmeli derslerde özellikle teoriye ve alan derslerine ağırlık verilmemesi gerektiği, bu bakımdan derslerdeki çeşitliliğin daha fazla artırılması ile ders dağılımında sorun yaşanmayacağı düşünülmektedir. Ayrıca seçmeli derslerin içeriklerinin teknoloji ve materyal yönünden geliştirilmesi gerektiği anlaşılmaktadır.

Derslerin Kredileri alt temasına ait öğretim elemanı görüşlerinden elde edilen verilere ilişkin kodlamalar Tablo 6' da sunulmuştur.

Tablo 6. Öğretim Elemanlarının Derslerin Kredilerine İlişkin Görüşleri

\begin{tabular}{lllll}
\hline Alt Tema & Kategori & Kod & Katılımc Kodları & Frekans (f) \\
\hline & Olumlu & Tamamı için olumlu & K1, K6, K7 & 3 \\
& Olumsuz & $\begin{array}{l}\text { Derslerin kredilerinin azalması } \\
\text { bakımından olumsuz, özellikle de alan } \\
\text { dersleri için }\end{array}$ & K2, K3, K4, K5, & 7 \\
Kredileri & Görüşler & $\begin{array}{l}\text { Alan dersleri için krediler yeterli değil, K12 } \\
\text { onun dişındakiler için olumlu }\end{array}$ & K9, K11 & 2 \\
& $\begin{array}{l}\text { Hem Olumlu } \\
\text { Hem Olumsuz } \\
\text { Görüşler }\end{array}$ & $\begin{array}{l} \\
\end{array}$ & & \\
\hline
\end{tabular}


Tablo 6'ya bakıldığında derslerin kredilerine ilişkin öğretim elemanlarının olumlu ya da olumsuz görüş bildirmesinin yanı sıra olumlu ve olumsuz görüşü birlikte sunanların ( $\mathrm{f}=2$ ) olduğu da görülmektedir. Özellikle öğretim elemanlarının çoğu (f=7) tarafından derslerin kredilerinin, kredilerin azalması yönünden olumsuz bulunması dikkat çekmektedir.

K1: “Alan bilgisi derslerinin kredilerinin azalmış olması öğrencilerin bunalmamasını sağlar. Sürekli pür aldıkları düşüncesi azalıp meslek bilgisi alıyoruz düşüncesi olacaktır."

K10: "Pür dersler açısından az buldum. Krediler düşmüş, baya bir bilgi var, verilmesi zor olabilir.”

K1 tarafından kredilerin azalması sayesinde öğrencilerde daha çok mesleğe yönelik eğitim aldıkları algısının yükseleceği düşünülmektedir. K10 ise burada öğretim elemanlarının yaşayacağı zorluğa dikkat çekmektedir. Bu bakımdan kredi ve içeriğin uyumlu olması gerektiğine dikkat çekilebilir.

Derslerin İçerikleri alt temasına ait öğretim elemanı görüşlerinden elde edilen verilere ilişkin kodlamalar Tablo 7'de sunulmuştur.

Tablo 7. Öğretim Elemanlarının Derslerin İçeriklerine İlişkin Görüşleri

\begin{tabular}{lllll}
\hline Alt Tema & Kategori & Kod & Katılımc Kodları & Frekans (f) \\
\hline & Olumlu & Tamamı için olumlu & K1, K2, K7, K10 & 4 \\
& Görusler & Alan bilgisi derslerinin içerikleri & K3, K4, K5, K6, & 7 \\
$\begin{array}{l}\text { Derslerin } \\
\text { İçerikleri }\end{array}$ & Olumsürüler & yetişmeyeceği için olumsuz & K8, K9, K12 & 1 \\
& $\begin{array}{l}\text { Hem Olumlu } \\
\text { Hem Olumsuz } \\
\text { Görüşler }\end{array}$ & $\begin{array}{l}\text { Öğtim dersleri için olumlu ama } \\
\text { alanisi dersleri için olumsuz }\end{array}$ & K11 & \\
\hline
\end{tabular}

Tablo 7'ye bakıldığında derslerin kredilerine ilişkin öğretim elemanlarının olumlu ya da olumsuz görüş bildirmesinin yanı sıra olumlu ve olumsuz görüşü birlikte sunan $(f=1)$ bir öğretim elemanının olduğu da görülmektedir. Ayrıca katılımcıların çoğunun $(f=7)$ derslerin içeriklerine ilişkin görüşlerinin olumsuz yönde olduğu anlaşılmaktadır. Bunun nedeni olarak alan bilgisi derslerinin içeriklerinin yetişmeyeceği düşüncesi gösterilebilir. Krediler öğretim dersleri açısından yeterli görülse de genel olarak alan bilgisi derslerinin içeriklerinin yetiştirilmesi noktasında yeterli görülmemektedir.

K11: “Öğretim derslerinin içerikleri çok hoşuma gitti. Hakkıyla verilirse ögrrencileri pedagojik formasyon açısından çok iyi yetiştireceğini düşünüyorum. Alan derslerinde 
içerik gerçekçi değil, yani kredi azalıyorsa içerik de azaltılmalıydı. Öğretim elemanlarını zora sokuyor."

Derslerin içerikleri ile ilgili görüşlere bakıldığında; alan bilgisi derslerini anlatan öğretim elemanlarının konuları yetiştiremeyeceği ya da önemli konular üzerinde duramayacağı gibi sorunlar ortaya çıkabilir. Bu açıdan içeriklerinin azalmaması nedeniyle derslerin içerikleri ile kredilerinin uygun şekilde olmadığı anlaşılmaktadır. Bu durum öğretim elemanları tarafından derslerin kredileri ile içeriklerinin örtüşmemesi noktasında yenilenen programın eleştirildiğini göstermektedir.

Derslerin Sınıf Düzeyine Uygunluğu alt temasına ait öğretim elemanı görüşlerinden elde edilen verilere ilişkin kodlamalar Tablo 8'de sunulmuştur.

Tablo 8. Öğretim Elemanlarının Derslerin Sınıf Düzeyine Uygunluğuna İlişkin Görüşleri

\begin{tabular}{lllll}
\hline Alt Tema & Kategori & Kod & Katılımcı Kodları & Frekans(f) \\
\hline & Olumlu & Dersler sı̈nıf düzeyine uygun & K2, K3, K4, K5, K7, & 10 \\
$\begin{array}{l}\text { Derslerin } \\
\text { Sinıf }\end{array}$ & Olumsuz & $\begin{array}{l}\text { Ortaokul Matematik Öğretim Programları K10, K11, K12 } \\
\text { Düzeyine }\end{array}$ & K1 & 1 \\
Uygunlü̆şsler & dersi sınıf düzeyine uygun değil & & \\
& & $\begin{array}{l}\text { Özel Öğretim Yöntemleri dersi sınıf } \\
\text { düzeyine uygun değil }\end{array}$ & K6 & 1 \\
\hline
\end{tabular}

Tablo 8 incelendiğinde öğretim elemanlarının çoğunun ( $\mathrm{f}=10)$ derslerin sınıf düzeyine uygunluğunu olumlu bulması dikkat çekmektedir.

K2: “Mesela 'Matematik Tarihi'nin başa alınması güzel. 'Analiz' derslerinin kaydırılması da mantıklı ve güzel olmuş. Bir öğretmenin mesleğine baklş açısını değiştireceği derslerin daha erken verilmesi gerektiğini düşünüyorum."

Olumsuz bulunan noktalar ise iki ayrı öğretim elemanı tarafından belirtilen sadece iki ayrı alan eğitimi dersi olmuştur.

K1: “'Ortaokul Matematik Öğretim Programları' dersini 2.sınfin 2.dönemi almaya başllyorlar, bunu 2.sınıfin 1.döneminde alabilirler. Böylece 'Öğretim İlke ve Yöntemleri' ile 'Matematik Öğretiminde Materyal Tasarımı' dersleri için çalışmalarını program doğrultusunda yapabilirler. Sıralamaya bakıldı̆̆ında yeni program çok daha anlaml, ama onda da yine bu tip eksikler var."

K6: “' 'Özel Öğretim Yöntemleri’ dersi keşke 1.sınıfa alınsaydı. Öğrenciler de; 'Keşke bu dersi 1.sınıfta alsaydık. Hocam çok geç oldu, keşke biz bunları başta ögrenseydik de ona göre diğer derslerimizi dizayn etseydik' diyorlar." 
K2 tarafından bazı derslerin daha erken verilmesinin öğretmen adaylarının mesleğine olan bakış açısına olumlu etki edeceği düşünülerek bu açıdan programın olumlu değerlendirildiği görülmüştür. K1 tarafından ifade edilen görüşlere bakıldığında Ortaokul Matematik Öğretim Programları dersinin bazı derslerden daha önce alınmamasının sorun oluşturabileceği ve bu dersin daha erkene alınması gerektiği belirtilebilir. Benzer şekilde K6 ise daha erken verilmesi gereken başka bir dersin de Özel Öğretim Yöntemleri olduğunu ifade etmiştir. Buradan hareketle derslerin sınıf düzeyine uygunluğu bakımından programın genel olarak olumlu bulunduğu ama hala geliştirilebilir yönlerinin olduğu düşünülmektedir.

\section{Yenilenen İMÖP Bağlamında Yaşanan/Yaşanabilecek Sorunlarla İlgili Görüşlere}

\section{Yönelik Bulgular}

Yaşanan/yaşanabilecek sorunlarla ilgili görüşler teması içerisinde öğretim elemanlarından alınan görüşler; kurumsal boyut, öğrenci boyutu ve materyal boyutu şeklinde alt temalara ayrılmıştır. Bu alt temalara ilişsin görüşlere göre kodlamalar yapılmıştır.

Kurumsal Boyut alt temasına ait öğretim elemanı görüşlerinden elde edilen verilere ilişkin kodlamalar Tablo 9'da sunulmuştur.

Tablo 9. Öğretim Elemanlarının Kurumsal Boyutta Yaşanan/Yaşanabilecek Sorunlara İlişkin Görüşleri

\begin{tabular}{|c|c|c|c|c|}
\hline Alt Tema & Kategori & Kod & Katılımeı Kodları & Frekans (f) \\
\hline \multirow{5}{*}{$\begin{array}{l}\text { Kurumsal } \\
\text { Boyutta } \\
\text { Sorunlar }\end{array}$} & $\begin{array}{l}\text { Olumlu } \\
\text { Görüşler }\end{array}$ & Kurumsal boyutta sorun yok & K8, K9 & 2 \\
\hline & \multirow{4}{*}{$\begin{array}{l}\text { Olumsuz } \\
\text { Görüşler }\end{array}$} & Öğretim elemanı eksikliği/fazlalığı & K1, K2, K4, K7, K10, K11 & 6 \\
\hline & & Altyap1 sorunu & K5, K6, K7 & 3 \\
\hline & & Bilgilendirme eksikliği & K3 & 1 \\
\hline & & Uyum/intibak sorunu & K12 & 1 \\
\hline
\end{tabular}

Tablo 9 incelendiğinde öğretim elemanlarının çoğunun (f=10) kurumsal boyutta sorunların olabileceğini belirttiği görülmektedir. Bunun nedeni olarak da yenilenen programda alan bilgisi derslerinin azaltılması ve özellikle öğretime yönelik yeni derslerin eklenmesi ile genel olarak öğretim elemanı eksikliği veya fazlalığının yaşanabileceği öngörülmüştür.

K1: "Meslek bilgisine ă̆ırlık verilmesiyle buna yönelik hocaların gerekliliği ortaya çıkıyor. Öğretim görevlisi eksikliği oluşabilir. Doğal olarak pedagojik formasyon dersi almış alan hocalarının olması gerektiğini düşünüyorum.",

K10: "Birçok ders açılmış, ögretim görevlisi eksikliği olacak. Pür matematik çalışan hoca sayısı fazla ve bunlar boşa çıkıyor. Böyle durumlar olabilir.” 
Öğretim elemanlarının görüşleri incelendiğinde kurumsal boyutta yaşanabileceği ifade edilen sorunların temel nedeni olarak; alan eğitimine yönelik yeni açılan birçok dersin olması ve alan bilgisi derslerinin kredilerinin azalması gösterilebilir. Katılımcıların yarısı, kurumsal boyuttaki sorunların genellikle bu nedenle yaşanacağını ifade etmiştir. Belirtilen görüşlere göre, alan bilgisi dersi veren öğretim elemanlarının fazlalığı oluşabilir. Bunun önlenmesi ve alan eğitimi dersi verecek öğretim elemanlarının eksikliği sorununun giderilmesi için, öğretim elemanlarının pedagojik formasyon alması gerektiği düşünülmektedir. Bir diğer çözüm olarak, alan eğitimi dersi veren öğretim elemanlarının da alan bilgisi dersleri yönünden kendilerini geliştirmeleri sağlanabilir.

Öğrenci Boyutu alt temasına ait öğretim elemanı görüşlerinden elde edilen verilere ilişkin kodlamalar Tablo 10'da sunulmuştur.

Tablo 10. Öğretim Elemanlarının Öğrenci Boyutunda Yaşanan/Yaşanabilecek Sorunlara İlişkkin Görüşleri

\begin{tabular}{lllll}
\hline Alt Tema & Kategori & Kod & Katılımcı Kodları & Frekans (f) \\
\hline & $\begin{array}{l}\text { Olumlu } \\
\text { Görüşler }\end{array}$ & Öğrenci boyutunda sorun yok & $\begin{array}{l}\text { K1, K2, K4, K7, K10, } \\
\text { K11 }\end{array}$ & 5 \\
$\begin{array}{l}\text { Öğrenci } \\
\begin{array}{l}\text { Boyutunda } \\
\text { Sorunlar }\end{array}\end{array}$ & $\begin{array}{l}\text { Olumsuz } \\
\text { Görüşler }\end{array}$ & Eski öğrenciler karmaşa yaşayabilir & K4, K7, K10, K12 & 4 \\
& $\begin{array}{l}\text { Kamu Personeli Seçme Sınavı [KPSS] } \\
\text { yeni programa göre düzenlenmeli }\end{array}$ & K1, K2 & 2 \\
& Güvensizlik oluşacak & K5 & 1 \\
\hline
\end{tabular}

Tablo 10'da öğretim elemanlarının bir kısmının ( $\mathrm{f}=5)$ öğrenci boyutunda sorun yaşanmayacağını düşündüğg̈ ancak çoğunun (f=7) sorun yaşanacağını ifade ettiği anlaşılmaktadır. En çok dikkat çeken ise eski öğrencilerin karmaşa yaşaması durumu olmuştur.

K12: “Eski ögrencilerin dersi devam ettirmesinde sıkıntı olabilir. Mesela dersin ismi aynı ama bir sürü içeriği değişmiş, kredisi değişmiş. Alttan ders alan olunca o dersi ögrenciye bir daha açmak gerekiyor. Çünkü arkadan gelen ders onu karşılamıyor.”

$\mathrm{Bu}$ sorunun kısa vadeli, yani geçici olduğu göz önünde bulundurulursa; daha az belirtilmiş olsa da uzun vadeli sorun olmaları bakımından diğer sorunlara da dikkat çekilmesi önemli görülmektedir.

K2: “Öğrenciler daha pragmatik açıdan olaya baktıkları için, yani diploma notu veya KPSS'ye yönelik sınavda da karşısına çıkacak bilgileri kaybetmelerinden ötürü, derslerin içeriği tam olarak verilemeyebilir. Bunu da önlerine çıkacak sınavlarla bu teorik derslerin veya uygulama derslerinin içeriklerinin biraz daha băgdaşması yoluyla çözülebileceğini düşünüyorum." 
K5: "Hoca yeterli değilse ögrrencide güvensizlik problemi oluşur."

Öğretim elemanlarının görüşleri incelendiğinde öğrenci boyutunda yaşanabilecek sorunlardan en önemli görülen, K12 tarafından da belirtildiği gibi alttan ders alan öğrenciler ile ilgili olmuştur. Kredilerin değişmesi ile birlikte alttan alınması gereken derslerin kredi veya içerik olarak denklik sağlamaması noktasında sorunlar yaşandığı ve yaşanacağı belirtilebilir. Bir yandan da yeni açılan dersleri verecek olan öğretim elemanlarının yetersiz olması durumunda öğrencinin öğrenmede yaşayacağı sorunlar da önemli görülmektedir. İleriye dönük yaşanabilecek sorunlara bakıldığında ise K2 tarafından ifade edilen sorun, programda kayda değer bir değişimin yaşandığı ve bu değişime göre yeni program ile KPSS'nin bağdaştırılmasının gerekli olduğu şeklinde yorumlanabilir.

Materyal Boyutu alt temasına ait öğretim elemanı görüşlerinden elde edilen verilere ilişkin kodlamalar Tablo 11'de sunulmuştur.

Tablo 11. Öğretim Elemanlarının Materyal Boyutunda Yaşanan/Yaşanabilecek Sorunlara İlişkin Görüşleri

\begin{tabular}{lllll}
\hline Alt Tema & Kategori & Kod & Katılımcı Kodları & Frekans(f) \\
\hline & $\begin{array}{l}\text { Olumlu } \\
\text { Görüşler }\end{array}$ & Materyal boyutunda sorun yok & K6, K7, K8 & 3 \\
$\begin{array}{l}\text { Materyal } \\
\begin{array}{l}\text { Boyutunda } \\
\text { Sorunlar }\end{array}\end{array}$ & $\begin{array}{l}\text { Olumsuz } \\
\text { Görüşler }\end{array}$ & $\begin{array}{l}\text { Yeni derslere yönelik kitaplar veya çeşitli } \\
\text { kaynaklar konusunda eksiklik var }\end{array}$ & K2, K3, K4, K5, K10, & 6 \\
& & $\begin{array}{l}\text { K12 } \\
\text { Öğretim derslerine yönelik özel sinıfların } \\
\text { açlması gerekiyor }\end{array}$ & K1, K9, K11 & 3 \\
\hline
\end{tabular}

Tablo 11'e bakıldığında öğretim elemanlarının çoğu ( $\mathrm{f}=9$ ) tarafından bu boyutla ilgili sorunların olduğu görülmektedir. Bu sorunların daha çok yeni derslerle ilgili kaynak bulma konusunda yaşanacağının düşünüldüğü anlaşılmaktadır.

K1: "Sınıflarımızın çoğunda akıllı tahta var ama onları da aktifkullanamıyoruz ne yazık ki. Hocaların da bu anlamda kendini yenilemesi ve geliştirmesi gerekir. Bunun da yapılması için matematik öğretim sınıfları oluşturulması gerekir. Bu eksiklik birçok üniversitede geçerlidir.”

K3: "Kullandı̆̆ımız kaynaklar, kitaplar vb. eskiye uygundur. Yeni derslere uygun kaynak da yok elimizde." şeklindedir.

K7: "Pür matematik anlattı̆̆ım için materyal kullanmıyorum."

Öğretim elemanlarının görüşleri incelendiğinde yarısının $(\mathrm{f}=6)$ yeni açılan derslerle ilgili sorunlara değindiği görülmektedir. Ayrıca öğretim elemanlarının bazıları ders materyalleri ve araç-gereç noktasında eksiklikler olabileceğini ve bunların hali hazırda da kullanımına ilişskin sıkıntılar çekildiğini ifade etmiştir. Bunun yanı sıra öğretim programında 
değişiklik olmasına rağmen alan bilgisi derslerini anlatan öğretim elemanlarının çoğunun kullandıkları materyallerde değişiklik yapma düşüncesinde olmadıkları anlaşılmaktadır. Bir yanda zaten materyallerin kullanılmadığı alan bilgisi dersleri varken, bir yanda da yeni açılan alan eğitimi derslerinde nasıl bir yol izleneceği merak edilmektedir. Özellikle yeni açılan öğretim dersleri için kaynaklara ihtiyaç duyulduğu ve bu derslerin yapısı gereği matematik öğretim sınıflarının açılması gerektiği ifade edilmektedir. Materyal boyutunda ifade edilen görüşlerin alan bilgisi ve alan eğitimi dersi veren öğretim elemanları arasında zıtlık gösterdiği dikkat çekmektedir. Oysa yenilenen programda alan bilgisi ile öğretimin birleştirilmesi esas alındığından, eksiklerin giderilmesi ve öğretim elemanlarının materyal kullanması önemli görülmektedir.

\section{Yenilenen İMÖP Bağlamında Programın Yeterlilikleri İle İlgili Görüşlere Yönelik Bulgular}

Programın yeterlilikleri ile ilgili görüşler teması içerisinde öğretim elemanlarından alınan görüşler; öğretmenlik mesleği açısından yeterliliği, teknolojinin eğitime entegrasyonu açısından yeterliliği ve matematik bilimini ögrenebilme ve ögretebilme açısından yeterliliğ $i$ şeklinde alt temalara ayrılmıştır. Bu alt temalara ilişkin görüşlere göre kodlamalar yapılmıştır.

Öğretmenlik Meslĕ̆i Açısından Yeterliliği alt temasına ait öğretim elemanı görüşlerinden elde edilen verilere ilişkin kodlamalar Tablo 12'de sunulmuştur.

Tablo 12. Yenilenen Programın Öğretmenlik Mesleği Açısından Yeterliliği İle İlgili Görüşler

\begin{tabular}{lllll}
\hline Alt Tema & Kategori & Kod & Katılımcı Kodları & Frekans (f) \\
\hline & Olumlu & Öğretmenlik mesleği açısından yeterli & K1, K4, K5, K7, K8, & 8 \\
Öğretmenlik & Görüşler & & K9, K10, K11 & \\
$\begin{array}{l}\text { Mesleği } \\
\text { Açısından }\end{array}$ & Olumsuz & Genel kültür eksikliği var & K2 & 1 \\
Yeterliliği & Görüşler & Matematik bilgisi eksikliği var & K3, K6, K12 & 3 \\
\hline
\end{tabular}

Tablo 12 incelendiğinde öğretim elemanlarının çoğunun $(\mathrm{f}=8)$ yenilenen programı öğretmenlik mesleği açısından yeterli bulduğu ancak bir kısmının bazı eksiklikler nedeniyle yeterli olmadığını düşündüğü anlaşılmaktadır.

K10: "Meslek bilgisi ve alan eğitimini öğretmeye yönelik çok sayıda ders açılmış. Yeterli, hatta fazlasının olduğunu düşünüyorum, oldukça başarıll."

K6: “Öğretmenlik yapıp yapmama noktasında değişiklikler iyi. Ama içeriğe baktığımız zaman sıkıntı var. Mesela çocuk dersi nasıl yapacă̆ını, konuya nasıl başlayacă̆ını, nasıl bitireceğini biliyor ama konuyu bilmiyor, sıkıntı orada."

Bazı öğretim elemanları, matematik bilgisinin eksik olmasının yeni program kapsamında yetiştirilecek olan ilköğretim matematik öğretmenlerinin mesleki bilgilerini 
olumsuz etkileyeceğini düşünmektedir. $\mathrm{Bu}$ görüş, matematik bilmeden matematiğin öğretilemeyeceği şeklinde yorumlanabilir. Katılımcıların bu görüşünün nedeni olarak alan bilgisi derslerinin kredilerinin azalması gösterilebilir. Bu açıdan K6 tarafından da benzer şekilde öğretim bilgisinin fazlaca verilmesinin, öğretilecek bilgiye hâkim olunamadığı sürece öğretmenlik mesleği açısından bir fayda sağlamayacağı ifade edilmiştir. Bu açıdan program bir bütünlük sağlamadığı gerekçesiyle eleştirilmiştir. Diğer taraftan K10 gibi birçok katılımcı tarafından programda yer alan derslerin yeterli olduğu düşünülmekte ve yenilenen programın öğretmenlik mesleği açısından olumlu bulunduğu görülmektedir.

Teknolojinin Eğitime Entegrasyonu Açısından Yeterliliği alt temasına ait öğretim elemanı görüşlerinden elde edilen verilere ilişskin kodlamalar Tablo 13'te sunulmuştur.

Tablo 13. Yenilenen Programın Teknolojinin Eğitime Entegrasyonu Açısından Yeterliliği İle İlgili Görüşler

\begin{tabular}{lllll}
\hline Alt Tema & Kategori & Kod & Katılımcı Kodları & Frekans (f) \\
\hline & $\begin{array}{l}\text { Olumblu } \\
\text { Görüler }\end{array}$ & $\begin{array}{l}\text { Teknolojinin eğitime entegrasyonu } \\
\text { açısından yeterli }\end{array}$ & K6, K7, K8, K9, & 5 \\
$\begin{array}{l}\text { Teknolojinin } \\
\text { Eğitime }\end{array}$ & Olumsuz & Derslerde uygulama yok & K1 & 1 \\
$\begin{array}{l}\text { Entegrasyonu } \\
\text { Açısından }\end{array}$ & Görüşler & Derslerde yeni teknolojiler kullanılmıyor & K2 & 1 \\
Yeterliliği & & Lersler yetersiz & K3, K4, K5, K10, & 5 \\
& & & K12 & \\
\hline
\end{tabular}

Tablo 13'e bakıldığında öğretim elemanlarının bir kısmı $(\mathrm{f}=5)$ teknolojinin eğitime entegrasyonu açısından programı yeterli görürken, bir kısmının $(f=7)$ ise genellikle derslerin bu yeterliliği sağlayacak sayıda ve içerikte olmadığını düşündükleri anlaşılmaktadır.

K1: “Teknolojiyi hiçbir şekilde entegre etmemişler. İşin garip tarafi uygulamalı ders yok, derslerin hepsi teorik. Bir kere teknolojiyi entegre ettiğimiz derslerin de içeriğini ona göre düzenlememiz gerekir ki ona göre de uygulama olması gerekir.”

K2: “Asla yeterli bulmuyorum. Çünkü hala materyal tasarımında biz tepegözleri bile anlatıyoruz. Hâlbuki şu an tepegöz diye bir şey yok. Yani şu an baktığımız zaman bizim birçok imkanımız var fakat bunları biz işe koşmuyoruz, sadece teoride kalıyor."

K4: "Kesinlikle yeterli değil. İki küçük ders ismi değişmesiyle bu iş olacak değil."

K10: "Algoritma diye bir ders açılmış ama yeterli değil. 5 yıl sonra için belki geri kalmış bir program ki bir program uzun süreli kullanılmalı. Bu açıdan yetersiz kalmış.",

Öğretim elemanlarının görüşleri incelendiğinde K1 tarafından, yenilenen programın teknolojinin eğitime entegrasyonu açısından en büyük eksikliği, derslerde uygulama olmaması olarak ifade edilmiştir. Eğitimde teknoloji kullanımının olması için derslerin kredilerinin sadece 
teorik kısmın öğrenilmesine değil, aynı zamanda uygulamaların yapılmasına yetecek şekilde düzenlenmesi gerekmektedir. Bu bakımdan gerekli bilgi ve donanıma sahip öğretmenlerin yetişmesi adına, programda yeniden düzenlemelerin gerekli olduğu belirtilebilir. Bir yandan da halen derslerde tepegözlerden bahsedilmesi ile K2 tarafından çarpıcı bir noktaya değinilmektedir. $\mathrm{Bu}$ durum teknolojinin eğitime entegre edilmesinden önce, teknoloji kullanımına yönelik çağa uyum sağlanması ve bunların öğretim elemanları tarafından da kullanılması için çalışmalar yapılması gerektiği şeklinde yorumlanabilir. Aksi halde K4 tarafından da ifade edildiği gibi sadece ders ismi değişecektir. Yani burada derslerin yüzeysel olarak geçilmesi ancak derinlemesine öğrenmenin gerçekleşmemesi durumu eleştirilmiştir. K10 ise bu yeterliliği sağlamaya yönelik açılan dersler için de geç kalındığını ifade etmiştir. Teknolojinin eğitime entegrasyonu açısından daha ileri görüşlü bir programın gerekliliği üzerinde durulmuştur.

Matematik Bilimini Öğrenebilme ve Öğretebilme Açısından Yeterliliği alt temasına ait öğretim elemanı görüşlerinden elde edilen verilere ilişkin kodlamalar Tablo 14'te sunulmuştur.

Tablo 14. Yenilenen Programın Matematik Bilimini Öğrenebilme ve Öğretebilme Açısından Yeterliliği İle İlgili Görüşler

\begin{tabular}{|c|c|c|c|c|}
\hline Alt Tema & Kategori & Kod & Katılımcı Kodları & Frekans (f) \\
\hline \multirow{4}{*}{$\begin{array}{l}\text { Matematik } \\
\text { Bilimini } \\
\text { Öğrenebilme ve } \\
\text { Öğretebilme } \\
\text { Açısından } \\
\text { Yeterliliği }\end{array}$} & $\begin{array}{l}\text { Olumlu } \\
\text { Görüşler }\end{array}$ & Her iki açıdan yeterli & K2, K4, K5, K7 & 4 \\
\hline & $\begin{array}{l}\text { Olumsuz } \\
\text { Görüşler }\end{array}$ & Her iki açıdan yetersiz & K3, K6, K12 & 3 \\
\hline & $\begin{array}{l}\text { Diğer } \\
\text { Görüşler }\end{array}$ & $\begin{array}{l}\text { Öğrenebilme açısından yetersiz, } \\
\text { öğretebilme açısından yeterli }\end{array}$ & K8, K9, K10, K11 & 4 \\
\hline & & Bireyin kendisine bağlı bir durum & K1 & 1 \\
\hline
\end{tabular}

Tablo 14 incelendiğinde en çok ifade edilen görüşlerin; programın her iki açıdan yeterli olduğu ( $\mathrm{f}=4)$ veya öğrenebilme açısından yetersiz ancak öğretebilme açısından yeterli $(\mathrm{f}=4)$ olduğu anlaşılmaktadır.

K11: "Matematikçi mantı̆̆ıyla bakılırsa çok eksik var ama öğretmen mantı̆̆lyla bakılırsa çok iyi. Öğretmenler matematikçi değildir. Bu açıdan yeterlidir. Ama matematiği öğrenme açısından eksik.”

K12: "Matematik alan bilgisi ögreniminin az olması onları meslek hayatında da olumsuz etkileyecek şeklinde düşünebiliriz.”

K11 tarafından programın matematik bilimini öğrenebilme ve öğretebilme açısından yeterliliği ile ilgili iki taraflı bir bakış açısı sunulduğu görülmektedir. Bir taraftan programın matematiği öğrenebilme açısından eksik ve yetersiz olduğu, bir yandan da öğretmenlerin bilim 
insanı değil eğitimci olmaları nedeniyle yeterliliğin sağlandığı ifade edilmiştir. Bu görüşün nedeni olarak alan bilgisi dersleri azalırken yeni alan eğitimi derslerinin açılmış olması gösterilebilir. Bu açıdan K12 ile görüşleri benzer şekildedir. İfade edilen görüşten anlaşıldığı üzere, matematik bilimini öğrenme konusunda yeterliliği azalan bir bireyin matematik bilimini öğretme noktasında da yeterliliğinin azalacağı düşünülmektedir.

\section{Tartışma ve Sonuç}

$\mathrm{Bu}$ çalışmada 2018 yılında yenilenen ilköğretim matematik öğretmenliği lisans programı hakkında öğretim elemanlarının görüşleri araştırılmıştır. Elde edilen bulgular doğrultusunda bu çalışmada, yenilenen programda alan bilgisi ve alan eğitimi ile ilgili yapılan değişiklikler üzerine odaklanılmıştır. Bu bölümde, elde edilen bulgular tartışılmış ve ulaşılan sonuçlar okuyucuya sunulmuştur.

Kapatılan derslerle ilgili elde edilen bulgularda Elementer Sayı Kuramı, Genel Matematik ve Geometri derslerine yönelik hem olumlu hem olumsuz görüşler ifade edilmiştir. Burada aynı dersler üzerine oldukça zıt görüşlerin ifade edilmiş olması dikkat çekmektedir. Bunun nedeni olarak; bazı öğretim elemanlarının derslerin öğretmen adaylarının ortaokulda matematik öğretiminde kullanılabilirliğine göre olması gerektiğini düşünmeleri, bazılarının ise alan bilgisi derslerinde önbilgileri oluşturacak şekilde derslerin verilmesi gerektiğini düşünmeleri gösterilebilir. Yani öğretim elemanlarının kapatılan derslerle ilgili değişimlere bazı noktalarda öğretmen adaylarının açısından bazı noktalarda da dersleri verecek olan öğretim elemanlarının açısından yaklaştıkları söylenebilir. Literatüre bakıldığında 2018 öncesi programın incelendiği bir araştırmada ilköğretim matematik öğretmen adaylarının Geometri dersinin kapatılmasını istedikleri ifade edilmiştir (Artut ve Bal, 2005). Bu doğrultuda Geometri dersinin kapatılmasının olumlu görülmesine yönelik elde ettiğimiz bulgular, yapılan çalışma ile paralellik göstermektedir. Genç ve Akıncı (2019) tarafından yapılan araştırmaya bakıldığında da öğretmen adaylarına göre; duyuşsal gelişime en çok fayda sağlayan dersin Elementer Sayı Kuramı, konu alan bilgisine en çok fayda sağlayan dersin Genel Matematik, matematiksel düşünme ile matematiksel akıl yürütme ve ispat yapabilmeye en çok fayda sağlayan dersin ise Geometri olduğu görülmüştür. Bu çalışmanın sonuçları ile elde ettiğimiz bulgularda kapatılan derslerle ilgili ifade edilen olumsuz görüşler paralellik göstermektedir. Ayrıca kapatılması olumsuz bulunan derslerle ilgili olarak yenilenen program ile birlikte ekolojik sorunlar yaşandığı söylenebilir. Ekolojik sorun; bir kavramın öğretildiği yer (habitat), o yerdeki işlevi 
ve diğer kavramlarla ilişkisi (niş) olarak (Sağlam Arslan, 2016) özetlenirse, bazı öğretim elemanlarının Genel Matematik ile Analiz arasında öncelik-sonralık ilişkisinin koparılmasından dolayı ekolojik sorunlar ortaya çıkabileceği endişesini taşıdığı belirtilebilir. Birbiri üzerine konumlandırılmış konulardan oluşan matematikte, bir konunun tam olarak anlamlandırılamaması, ilişkili ya da devamı niteliğinde olan başka konuların öğreniminde güçlüklerin ortaya çıkmasına sebep olabilmektedir (Kuzu, 2017). Bu durum ise, soyut düşünme ve problem çözme gibi üst düzey bilişsel becerilerdeki performansları ve öğrenim sürecini olumsuz etkileyebilmektedir (Chappell ve Killpatrick, 2003; Hiebert ve Carpenter, 1992; Sevimli, 2013). Örneğin Genel Matematik dersi alınmadan Analiz derslerinin alınması, analiz derslerinde öğretilen bazı matematiksel kavramların ön öğrenmeleri olmaksızın öğretilmesini zorunlu kılacağından ekolojik bir sorun olarak yorumlanabilir. Bununla birlikte genel matematik dersinin kaldırılması ve eski programda 2. sınıfta verilen analiz 1 dersinin yenilenen programda 1.sınıfın 1. dönemine çekilmesi öğretmen adaylarının analiz derslerindeki hazırbulunuşluğunu da etkileyebileceği anlaşılmaktadır.

Yeni açılan derslerle ilgili elde edilen bulgularda tüm katılımcıların görüşleri olumlu yönde olmuştur. Özellikle öğretim derslerinin gerekli ve faydalı olduğu ifade edilmiştir. Demircan (2010) tarafından yapılan araştırmada öğretmen adayları ve öğretmenler tarafından alan bilgisi derslerinin meslekte kullanılabilirliğinin olmadığı ifade edilmiştir. Bu açıdan alan derslerinin öğretimine yönelik yeni derslerin açılmasının, alan derslerinin meslekte kullanılabilir olmasını sağlayacağı düşünülebilir. Bu çalışmada elde edilen bulgulara göre de yenilenen programda alan eğitimi derslerindeki artışın, teorik olarak verilen alan eğitiminin pratikte yapılabilirliği ile ilgili pozitif yansımalarının gözlenme potansiyelinin yüksek olduğu söylenebilir. Benzer şekilde Genç ve Akıncı (2019) tarafından yapılan çalışmada da öğretilen matematiği daha anlamlı kılacak şekilde konu alan bilgisine ek olarak matematiksel kavramları gerçek yaşam durumları ile ilişkilendiren matematiksel konu alan bilgisi öğretimine vurgu yapılmaktadır. Dolayısıyla yenilenen programın ileride ilköğretim matematik öğretmeni olacak adayların sahip olması gereken bilgiler açısından bir paradigma dönüşümü ihtiva ettiği belirtilebilir. Bu değişimin literatürdeki değişimle paralel bir şekilde (Appelbaum, Friedler, Ortiz ve Wolff, 2009; Marchese, 2006) alan bilgisinin öğretiminden alan eğitiminin öğretimine kaydığg belirtilebilir.

Seçmeli derslerle ilgili elde edilen bulgularda, öğretim elemanlarının çoğunun programda esnekliğin sağlaması bakımından seçmeli dersleri olumlu bulduğu görülmüştür. 
Bazı öğretim elemanlarının ise; seçmeli derslerin çoğunun alan bilgisine yönelik olması, öğretilmesine yönelik eksiklikler olması, önceden zorunlu olup sonradan seçmeli olan derslerin olması ve derslerin öğretim elemanlarına dağıtılması noktasında yaşanabilecek zorluklar yönünden seçmeli dersleri olumsuz buldukları anlaşılmıştır. Yenilenen programda seçmeli ders oranının arttırıldı̆̆ı görülmüştür (Özdemir, 2018; YÖK, 2018). Bu durum, seçmeli derslerle yenilenen programda daha fazla esneklik sağlanması görüşünün nedeni olarak gösterilebilir. Sınıf öğretmenliği lisans programına yönelik benzer bir çalışmada, katılımcılardan biri seçmeli derslerin mesleki ihtiyaçları karşılayacak şekilde olması gerektiğini ifade etmiştir (Kılıç Özmen, 2019). Diğer taraftan Demircan (2010) tarafından yapılan araştırmada katılımcılardan biri, alan derslerinin bir kısmının seçmeli olması gerektiğini ve isteyen öğrencilerin bu dersleri alıp istemeyen öğrencilerin ise almaması gerektiğini ifade etmiştir. Yenilenen programda seçmeli derslerde alan derslerine ağırlık verilmesinin bu ifade ile paralellik gösterdiği anlaşılmaktadır. Ancak bu çalışmada katılımcılardan biri tarafından seçmeli derslerin çoğunun alan bilgisine yönelik olmasının eleştirilmesi ve seçmeli derslerin çeşitlendirilmesi gerektiğinin ifade edilmesi yönünden paralellik göstermediği anlaşılmaktadır.

Derslerin kredileri ile ilgili elde edilen bulgulara göre krediler, alan bilgisi dersleri açısından olumsuz bulunmuş ve diğer dersler açısından olumlu görüşler ifade edilmiştir. Çalışmada derslerin içerikleri ile ilgili de derslerin kredilerinden yola çıkılarak alan bilgisi derslerine yönelik olumsuz görüşler ifade edilmiş olup, diğer dersler açısından olumlu görüşler ifade edilmiştir. Olumsuz görüşlerin nedeni olarak alan bilgisi derslerinin içeriklerinin verilen süre/kredi içerisinde yetiştirilmesinin zor olacağ 1 ve bu durumun öğretim elemanlarının işini zorlaştıracağı söylenebilir. Yapılan çalışmada derslerin içerikleri ile ilgili olumlu görüşler özellikle öğretim dersleri için belirtilmiş olup, bu görüşler Kaymakçı, Keskin ve Ev Çimen (2018) tarafından yapılan çalışmada ifade edilen lisans programında ortaokul konularına alt yapı oluşturan içeriklerin yer alması gerektiği görüşü ile paralellik göstermektedir. Erol (2013) tarafından yapılan çalışmada da katılımcılar tarafından ders içeriklerinin; gerçek hayatla bağlantılı, teorik ve uygulamalı bilgileri dengede sunarak, daha aktif şekilde kullanabilecekleri yöntem ve tekniklere yer verecek şekilde dikkate alınması gerektiği ifade edilmiştir.

Baştürk (2011) tarafından yapılan çalışmada öğretmen adayları tarafindan bazı derslerin sınıf seviyesinin değiştirilmesi önerilmiştir. $\mathrm{Bu}$ doğrultuda bu çalışmada derslerin sınıf düzeyine uygunluğu ile ilgili olarak da öğretim elemanlarının görüşleri alınmıştır. Bu bakımdan programda değişikliğe uğrayan derslerden özellikle Matematik Tarihi dersinin uygun olduğu; 
Ortaokul Matematik Öğretim Programları ve Özel Öğretim Yöntemleri derslerinin ise daha erken dönemlerde verilmesi gerektiği düşünülerek uygun olmadığg ifade edilmiştir. Yenilmez (2011) tarafından yapılan çalışmada öğretmen adayları tarafından Matematik Tarihi dersinin öğrencilerin sorularına cevap verebilme, matematiği sevdirme, ilgi ve motivasyonu sağlama bağlamında her matematikçi tarafından öğrenilmesi gerektiğini ifade edilmiştir. Buna paralel olarak bu çalışmada öğretim elemanları tarafından Matematik Tarihi dersinin yenilenen program ile birinci yarıyıla alınmasının öğretmen adayları için olumlu olacağı görüşünün egemen olduğu anlaşılmaktadır. Sonuç olarak derslerin sınıf düzeyine uygunluğu bakımından yenilenen programın genel olarak olumlu bulunduğu ama hala geliştirilebilir yönlerinin olduğu söylenebilir.

Kurumsal boyuttaki sorunlarla ilgili elde edilen bulgularda özellikle bazı derslerin kredilerinin azalması ve bazı yeni derslerin açılması nedeniyle üniversitelerde öğretim elemanı eksikliği/fazlalığı sorunu yaşanabileceği üzerinde durulmuştur. Ayrıca öğretim elemanlarının bilgilendirilmesi ve yeni programa uyum sağlamaları açısından da sorunlar yaşanabileceği ifade edilmiştir. Bunların yanı sıra öğretim elemanlarının alan eğitimi dersleri verebilmeleri için pedagojik formasyon altyapılarının olması gerektiği de ifade edilen görüşler arasındadır. Program değişimininin altında yatan bir nedenin de bu olduğu düşünülebilir. Çünkü yapılandırmacı anlayışa yönelik öğretim durumlarının halen öğretim ortamına tam anlamıyla yansıtılamadığı düşünülmektedir (Mertoğlu, Gürdal ve Akgül, 2019). Benzer şekilde yapılan bir araştırmada da öğretim elemanlarının yapılandırmacılık noktasında örnek olamadıkları ifade edilmiş olup, öğretmen adaylarının hangi yöntem teknikleri kullanmaları isteniyorsa aynı şekilde matematik öğrenmeleri gerektiği savunulmuştur (Baştürk, 2011). Bunu sağlamak için yenilenen program ile bu konuda köklü bir dönüşüm yapılmak istenmiş olabilir. Bu değişimin ne derece etkili olacağının, öğretim elemanlarının öğretime yönelik gelişimlerinin ne derece sağlanacağı ile ilgili olduğu düşünülebilir. Bu konu ile ilgili Kılıç Özmen (2019) akademisyenlerde öğretmenlik tecrübesi bulunması gerektiğini, Polat ve Ünişen (2017) ise öğretim üyelerinin alan uzmanı olması kadar pedagojik yeterliliklerinin de olmasının gerektiğgini vurgulamıştır. Gökçek ve Baran Kaya (2017) tarafından yapılan çalışmada da öğretmen adayları akademisyenlerin farklı yöntem teknik konusunda beklentili oldukları halde kendilerinin sürekli düz anlatım kullandıklarını ifade edilmiştir. Bu konuda daha önce yapılan çalışmalara bakıldığında bu çalışmada elde edilen bulgular ile paralellik gösterdiği anlaşılmaktadır. Sonuçta, yenilenen program ile birlikte kurumsal boyutta öğretim elemanları 
tarafından öğretmen adaylarına örnek olacak şekilde yöntem ve teknikler kullanarak lisans eğitimi verilmesi gerektiği söylenebilir.

Öğrenci boyutundaki sorunlarla ilgili elde edilen bulgularda; alttan ders alan öğrencilerin karmaşa yaşaması, KPSS ile programın bağdaştırılması gerektiği, güvensizlik oluşması görüşleri ifade edilmiştir. En çok vurgulanan sorun olması nedeniyle alttan ders alan öğrencilerin karmaşa yaşamaması için programlar yenilenirken bu noktaya dikkat edilmesi gerektiği söylenebilir. Ancak bunun kısa vadeli bir sorun olması bakımından ifade edilen diğer görüşlere de dikkat çekilmesi önemli görülmektedir. Şahin ve Balkar (2007) tarafindan yapılan çalışmada derslerin KPSS ile uyumlu olması ve buna göre düzenlemelerin yapılması gerektiği ifade edilmiştir. Bu açıdan programın KPSS ile bağdaşması noktasında görüşlerin paralellik gösterdiği ve KPSS'nin yenilenen programlara göre revize edilmesi gerektiği söylenebilir.

Materyal boyutundaki sorunlarla ilgili elde edilen bulgularda, yeni derslere yönelik kaynak eksikliğinin olması ve öğretim dersleri için özel sınıfların olmaması yönünde görüşler belirtilmiştir. Yenilenen programda alan bilgisi ile öğretimin birleştirilmesi söz konusu olduğundan, eksiklerin giderilmesi ve öğretim elemanlarının materyal kullanması önemli görülmektedir. Bu çalışmada öğretim elemanları tarafından da ifade edildiği üzere materyal eksiklikler yaşanmaktadır. Dolayısıyla bu tür köklü ve hızlı program değişikliklerinde materyal (ders kitabı, araç-gereç, vs.) eksikleri yaşanabileceği söylenebilir. Bu doğrultuda yeni açılan derslere yönelik kaynak eksikliğinin en kısa zamanda giderilmesi ve eğitim fakültelerinde öğretim derslerine yönelik özel sınıfların oluşturulması gerektiği düşünülmektedir.

Yapılan çalışmada öğretim elemanlarının çoğu yenilenen programın öğretmenlik mesleği açısından yeterli olduğunu ifade etmiş olsa da bazı katılımcılar programın genel kültür bilgisi ve matematik bilgisi yönünden eksik olduğunu, bu nedenle de öğretmenlik mesleği açısından da yeterliliğin karşılanamadığını ifade etmişlerdir. Kaymakçı, Keskin ve Ev Çimen (2018) tarafından yapılan çalışmada ise katılımcılar meslek hayatlarında, yani ortaokulda matematik öğretirken, lisansta gördükleri matematik bilgisi derslerine ihtiyaç duymadıklarını ifade etmişlerdir. $\mathrm{Bu}$ çalışmada yer alan ifade, bulgularda elde edilen matematik bilgisi eksikliğinin programda öğretmenlik mesleği açısından yeterliliği sağlamayacağı görüşü ile çelişmektedir. Gökçek ve Baran Kaya (2017) tarafından yapılan çalışmada ise öğretmen adayları tarafından genel kültür derslerinin arttırılması gerektiğini ifade edilmiş olup, bu görüş ile çalışmada elde edilen programda genel kültür bilgisi eksikliğinin olduğu görüşü paralellik göstermektedir. 
Matematik eğitimi üzerinde gerçekleştirilen reform hareketleri ile yeni teknolojilerin öğretimde kullanılması, öğrencilere anlamlı etkinlikler sunulması ve bilgileri paylaşma firsatının verilmesi istenmektedir (National Council of Teachers of Mathematics [NCTM], 2000). Yapılan araştırmalarla çeşitli teknoloji entegrasyonu modelleri ortaya koyulmuş olup bu modellerde; teknoloji, pedagoji ve alan bilgisi bir bütün olarak kabul edilmiştir (Niess, 2005). Dolayısıyla teknolojinin eğitime entegrasyonunun bir gereklilik olduğu söylenebilir (Liao, 2007). Ancak bu çalışmada öğretim elemanlarının çoğu, yenilenen programı teknolojinin eğitime entegrasyonu açısından yeterli bulmamıştır. Bunun nedeni olarak da; derslerin uygulamalı olmaması, derslerde yeni teknolojilerin kullanılmaması ve derslerin bunu karşılamadaki yetersizliği ifade edilmiştir. Yenilenen lisans programına bakıldığında Algoritma ve Programa adıyla yeni bir dersin eklendiği görülmüştür. Programlama alıştırmalarının uygulanmasının öğrenciler için geniş çapta problem çözmeyi ve işbirliği içinde aktif olarak çalışmayı sağladığı, bu açıdan programlama becerilerinin kullanımı ile gerçekleştirilen entegrasyonun faydalı olduğu söylenebilir (Cline, Fasteen, Francis, Sullivan ve Wendt, 2019). $\mathrm{Bu}$ doğrultuda bu dersin açılmış olması katılımcılar tarafindan olumlu bulunsa da programda teknolojinin eğitime entegrasyonunun sağlanması bakımından yeterli bulunmamış olup, genel olarak derslerin bunu karşılamada yetersiz olduğu ifade edilmiştir. Ayrıca derslerde yeni teknolojilerin kullanılmaması da getirilen bir diğer eleştiri olmuştur. Bu doğrultuda lisans derslerinde de yeni teknolojilerin (artırılmış gerçeklik, sanal gerçeklik, hologram teknolojisi gibi) kullanılması gerektiği düşünülebilir. Bu teknolojilerin kullanılması noktasında da bir diğer eleştiri olarak yenilenen programda derslerde uygulama olmaması dikkat çekmektedir. Gökçek ve Baran Kaya (2017) tarafından yapılan çalışmada da öğretmen adayları tarafından derslerin fazla teorik olduğu ve uygulamanın da olması gerektiği ifade edilmiştir. Kaymakçı, Keskin ve Ev Çimen (2018) tarafından yapılan çalışmada ise hem öğretmenler hem de öğretmen adayları tarafından derslerde uygulama kısmının eksik olduğu ve pratikten uzak olup daha çok teorik şekilde işlendiği görüşünde oldukları ortaya koyulmuştur.

Yapılan çalışmada programın matematik bilimini öğrenebilme ve öğretebilme açısından yeterliliği ile ilgili farklı görüşler ortaya çıkmıştır. Bazı katılımcılar programın her iki yönden yeterli olduğunu, bazıları programın her iki yönden yetersiz olduğunu ve bir kısmı da programın matematik bilimini öğrenme açısından yetersiz ama öğretme açısından yeterli olduğunu ifade etmiştir. Katılımcılardan biri ise bunun öğretmen adayının kendisine bağlı bir durum olduğunu ifade etmiştir. Bu sonuç, Yeşilyurt (2019) tarafindan yapılan çalışmada elde edilen, öğrenme 
çıktılarının en çok öğretmen adayının kendisine bağlı olduğu sonucunu desteklemektedir. Katılımcıların çoğunun ifade ettiği görüşlere bakıldığında ise; yenilenen programda alan bilgisi derslerinin azalması ve öğretim derslerinin açılmasından dolayı, programın matematiği öğrenme açısından olumsuz ama öğretme açısından olumlu bir yönde değiştiği söylenebilir. Bazı görüşlerde ise alan bilgisi eksik olan bir öğretmen adayının öğretimde de zorlanacağı ve bu nedenle programın her iki açıdan yetersiz olduğu ifade edilmiştir. Buradan hareketle öğretim elemanlarının görüşlerinde bir ikilem yaşandığı gözlenmektedir. Elde edilen bulgulara göre alan bilgisi az veya çok olan öğretmenlerin matematik bilimini öğretmedeki yeterlilikleri arasında ne derece farklılık olacağı ile ilgili ifadeler tartışmalıdır. Bu duruma yönelik Genç ve Akıncı (2019) tarafından yapılan çalışmada; öğretmen adaylarının sadece öğretecekleri matematik bilgisine değil, bu bilgilerle diğer matematiksel kavramları ilişkilendirebilecek derin matematiksel bilgilere de sahip olmaları gerektiği belirtilmiştir. Bu doğrultuda öğretim dersleri matematik öğretimine katkısı bakımından desteklenmekle birlikte, alan bilgisi derslerinin de hem matematik öğrenimi hem de dolaylı olarak matematik öğretimi açısından önemli olduğu söylenebilir.

Sonuç olarak bu çalışmada: Yenilenen programda kapatılan derslerle ilgili zıt görüşlerin var olduğu; yeni açılan derslerin, seçmeli derslerin ve derslerin sınıf düzeyine uygunluğunun genel olarak olumlu görüldüğü; derslerin kredilerinin ve içeriklerinin alan bilgisi dersleri açısından olumsuz görüldüğü; kurumsal boyutta, öğrenci boyutunda ve materyal boyutunda birçok sorunun yaşandığı/yaşanabileceği; programın öğretmenlik mesleği açısından yeterli bulunduğu; katılımcıların çoğu tarafından teknolojinin eğitime entegrasyonu ile matematik bilimini öğrenebilme ve öğretebilme açısından programın bazı eksikleri olduğu anlaşılmıştır. Ayrıca elde edilen bulgulara göre; bu değişimle birlikte ekolojik sorunlar, materyal eksikliği, alan bilgisi eksikliği gibi sorunların yaşanabilecek olmasına rağmen, alan bilgisinin öğretimine ilişkin daha etkili bir programın oluşturulduğu sonucuna ulaşılmıştır.

\section{Öneriler}

Yapılan çalışmada ulaşılan sonuçlar doğrultusunda bir konsensüs oluşturularak alan bilgisi derslerinin kredileri ve içerikleri yeniden düzenlenebilir. KPSS yenilenen program ile bağdaştırılacak şekilde yeniden düzenlenebilir. Yeni eklenen dersler için çalışmalar yapılarak kısa sürede kaynak eksikleri giderilebilir ve fakültelerde öğretim derslerine yönelik özel sınıflar oluşturulabilir. Öğretim elemanları tarafından derslerde düz anlatım yerine, uygulamaya 
yönelik yeni teknolojilerden ve matematiksel programlardan yararlanılarak öğretmen adaylarına örnek olacak şekilde dersler yürütülebilir. $\mathrm{Bu}$ çalışmada sadece öğretim elemanlarının görüşleri alındığından, yeni bir çalışma ile öğretmenlerin ve öğretmen adaylarının da görüşleri alınabilir. Bu çalışmadaki gibi bir üniversitedeki öğretim elemanları ile çalışma yürütmek yerine farklı üniversitelerden katılımcılarla geniş katılımlı benzer çalışmalar yapılarak değişimin yansımaları incelenebilir. Daha uzun süreli boylamsal çalışmalarla buradaki sonuçların ne derece gerçekleştiği izlenebilir.

\section{Makalenin Bilimdeki Konumu}

Matematik ve Fen Bilimleri Eğitimi Bölümü/ Matematik Eğitimi Anabilim Dalı

\section{Makalenin Bilimdeki Özgünlüğü}

Alan yazında program değişiklikleri üzerine birçok çalışma yapılmaktadır. $\mathrm{Bu}$ çalışmalarda öğretim elemanlarının, öğretmenlerin ve öğretmen adaylarının görüşlerine yer verildiği görülmektedir.

Eğitim fakültesi lisans programlarında 2018 yılında yapılan değişiklikler ile ilgili çalışmalar yapılmış olsa da, ilköğretim matematik öğretmenliği lisans programında yapılan değişikliklerin incelendiği bir araştırmaya rastlanmamıştır. Ayrıca yapılan çalışmada öğretim derslerinin açılmış olması yönünden programda köklü bir değişimin olduğu gözlenmekte ve bu değişimin incelenmesi önemli görülmektedir. Bu bağlamda yapılan çalışmanın literatüre katkı sağlayacağı düşünülmektedir.

\section{Kaynaklar}

Aksu, H. H. (2016). Eğitim fakültesinde öğrenim gören öğrencilerin bölümleri hakkındaki görüşleri: Giresun Üniversitesi örneği. Kastamonu Ĕ̆itim Dergisi, 24(1), 299-316.

Alver, M., \& Aydın, E. (2019). Examination of the restructured Turkish teaching undergraduate program. International Education Studies, 12(11), 125-138.

Appelbaum, P., Friedler, L. M., Ortiz, C. E., \& Wolff, E. F. (2009). Internationalizing the university mathematics curriculum. Journal of Studies in International Education, 13(3), 365-381.

Aras, S., \& Sözen, S. (2012). Türkiye, Finlandiya ve Güney Kore'de öğretmen yetiştirme programlarının incelenmesi. X. Ulusal Fen Bilimleri ve Matematik Eğitimi Kongresi. Niğde Üniversitesi Eğitim Fakültesi, 27-30 Haziran, Niğde. 
Artut, P. D., \& Bal, P. (2005). İlköğretim matematik öğretmenliği lisans programının öğrenciler açısından değerlendirilmesi. Çukurova Üniversitesi Sosyal Bilimler Enstitüsü Dergisi, 14(2), 81-90.

Ball, D. L., Hill, H. C., \& Bass, H. (2005). Knowing mathematics for teaching: Who knows mathematics well enough to teach third grade, and how can we decide? American Educator, 29, 12-22.

Bartan, M. (2019). Okul öncesi öğretmen ve öğretmen adaylarının okul öncesi öğretmen yetiştirme lisans programı hakkında görüş ve önerileri. Dumlupınar Üniversitesi Ĕ̆itim Bilimleri Enstitüsü Dergisi, 3(1), 24-36.

Baştürk, S. (2011). Matematik öğretmen adaylarının eğitim fakültesindeki eğitim-öğretim sürecini değerlendirmeleri. Uluslararası İnsan Bilimleri Dergisi, 8(1), 58-94.

Berestova, A. V., Lazareva, A. V., \& Leontyev, V. V. (2020). New tendencies in studies with in vocational education in Russia. International Journal of Instruction, 13(1), 886-900.

Bilir, A. (2011). Türkiye'de öğretmen yetiştirmenin tarihsel evrimi ve istihdam politikaları. Journal of Faculty of Educational Sciences, 44(2), 223-246.

Büyüköztürk, Ş., Kılıç Çakmak, E., Akgün, Ö. E., Karadeniz, Ş., \& Demirel, F. (2008). Bilimsel Araştırma Yöntemleri. Ankara: Pegem A Yayıncılık.

Chappell, K. K., \& Killpatrick, K. (2003). Effects of concept-based instruction on students' conceptual understanding and procedural knowledge of calculus. Problems, Resources, and Issues in Mathematics Undergraduate Studies, 13(1), 17-37.

Cline, K., Fasteen, J., Francis, A., Sullivan, E., \& Wendt, T. (2019). Integrating programming across the undergraduate mathematics curriculum, PRIMUS, DOI: 10.1080/10511970.2019.1616637

Conference Board of the Mathematical Sciences. (CBMS). (2001). The mathematical education of teachers-issues on mathematics education (Vol. 11). Providence, RI: American Mathematical Society.

Demircan, A. (2010). İlköğretim matematik öğretmenliği programındaki alan derslerinin meslekteki kullanılabilirliğine dair ögrretmen ve öğretmen adayı görüşleri. Yüksek lisans tezi, Fen Bilimleri Enstitüsü Balıkesir Üniversitesi, Balıkesir.

Eraslan, A. (2009). İlköğretim matematik öğretmen adaylarının 'öğretmenlik uygulaması' üzerine görüşleri. Necatibey Eğitim Fakültesi Elektronik Fen ve Matematik Eğitimi Dergisi, 3(1), 207-221. 
Erol, B. (2013). İlköğretim matematik öğretmenliği 2. sinıf öğrencilerinin fizik dersine yönelik tutumları ile ögrenme stilleri arasındaki ilişki. Yüksek lisans tezi, Eğitim Bilimleri Enstitüsü Dokuz Eylül Üniversitesi, İzmir.

Genç, M., \& Akıncı, M. (2019). İlköğretim matematik öğretmen adaylarının lisans eğitiminde alınan matematik konu alan derslerine ilişskin görüşleri. Necatibey Eğitim Fakültesi Elektronik Fen ve Matematik Ĕgitimi Dergisi (EFMED), 13(1), 483-514.

Gök, M. (2016). Analysis of components of pedagogical content knowledge: Content knowledge and knowledge of learners. Route Educational and Social Science Journal, 3(2), 217-236.

Gökçek, T., \& Baran Kaya, T. (2017). Ortaokul matematik öğretmeni adaylarının bakış açısıyla öğretmenlik mesleği ve lisans eğitiminin niteliği. Ahi Evran Üniversitesi Kırşehir Ĕ̆itim Fakültesi Dergisi (KEFAD), 18(1), 131-153.

Grossman, G. M., \& Sands, M. K. (2008). Restructuring reforms in Turkish teacher education: Modernisation and development in a dynamic environment. International Journal of Educational Development, 28(1), 70-80.

Hiebert, J., \& Carpenter, T. P. (1992). Learning and teaching with understanding. In D. A. Grouns (Ed.), Handbook of Research on Mathematics Teaching and Learning (pp. 6597). New York: Macmillan.

Johnson, K. G., Nebesniak, A. L., \& Rupnow, T. J. (2019). District-university collaborations to support reform-based mathematics curriculum. Journal of Mathematics Education at Teachers College, 10(1), 17-20.

Karakaya, F., Adıgüzel, M., Çimen, O., \& Y1lmaz, M. (2020). 2018 Biyoloji öğretmenliği lisans programının öğretmen görüşlerine göre incelenmesi. Türk Eğitim Bilimleri Dergisi, 18(1), 122-135.

Karataş, Z. (2015). Sosyal bilimlerde nitel araştirma yöntemleri. Manevi Temelli Sosyal Hizmet Araştırmaları Dergisi, 1(1), 62-80.

Kartal, M. (2011). Türkiye'nin alan öğretmeni yetiştirme deneyimleri ve sürdürülebilir yeni model yaklaşımları. Buca Eğitim Fakültesi Dergisi, 29, 50-57.

Kaymakcı, K., Keskin, E., \& Ev Çimen, E. (2018). Eskişehir ilindeki ilköğretim matematik öğretmenleri ve öğretmen adaylarının lisans eğitiminde aldıkları dersler üzerine görüşleri. Eskişehir Osmangazi Üniversitesi Türk Dünyası Uygulama ve Araştırma Merkezi Ĕ̈itim Dergisi, 3(1), 23-41. 
Kılıç Özmen, Z. (2019). 2018 Sınıf öğretmenliği lisans programının değerlendirilmesi. Anadolu Journal of Educational Sciences International (AJESI), 9(2), 521-548.

Kızılçaoğlu, A. (2006). Eğitim fakültelerinde yeniden yapılandırma sürecine ilişkin eleştiriler ve öneriler. Balıkesir Üniversitesi Sosyal Bilimler Enstitüsü Dergisi, 8(14), 132-140.

Liao. Y. C. (2007). Effects of computer-assisted instruction on students' achievement in Taiwan: A meta-analysis. Computers \& Education, 48 (2). 216-233.

Lincoln, Y. S., Lynham, S. A., \& Guba, E. G. (2011). Paradigmatic controversies, contradictions and emeging confluences, revisited. In N. K. Denzin \& Y. S. Lincoln (Eds.), The Sage handbook of qualitative research (4th ed.,pp. 99-128). Thousand Oaks, CA: Sage.

Kuzu, O. (2017). Matematik ve Fen Bilgisi öğretmen adaylarının integral konusundaki kazanımlarının incelenmesi. Kırşehir Eğitim Fakültesi Dergisi, 18(3), 948-970.

Marchese, T. J. (2006). Whatever happened to undergraduate reform, Carnegie Foundation perspectives number 26. Palo Alto, CA: The Carnegie Foundation forthe Improvement of Teaching.

Merriam, S. B. (2009). Nitel araştırma: Tasarım ve uygulama kılavuzu. San Francisco, CA: Jossey-Bass.

Mertoğlu, H., Gürdal, A., \& Akgül, E. M. (2019). Teori ve uygulamada yapılandırmacı yaklaşım. Eurasian Academy of Sciences Social Sciences Journal, 27, 145-165.

Miles, M, B., \& Huberman, A. M. (1994). Qualitative data analysis: An expanded Sourcebook. (2nd ed). Thousand Oaks, CA: Sage.

National Council of Teachers of Mathematics (NCTM), (2000). Principles and Standarts for School Mathematics. https://www.nctm.org/Standards-and-Positions/Principles-andStandards/

Niess, M. L. (2005). Preparing teachers to teach Science and Mathematics with technology: Developing a technology pedagogical content knowledge. Teaching and Teacher Education, 21(5), 509-523.

Özdemir, M. (2010). Nitel veri analizi: Sosyal bilimlerde yöntembilim sorunsalı üzerine bir çalışma. Eskişehir Osmangazi Üniversitesi Sosyal Bilimler Dergisi, 11(1), 323-343.

Özdemir, B. (2018). Matematik öğretmenliği ile matematik bölümü programlarının karşılaştırılması ve yeterlilikler çerçevesinde öğrenci görüşleri. Yüksek lisans tezi, Eğitim Bilimleri Enstitüsü Hacettepe Üniversitesi, Ankara. 
Polat, H., \& Ünişen, A. (2017). Sınıf eğitimi öğretmen adaylarının görüşlerine göre program derslerine giren öğretim üyelerinin pedagojik yeterlilikleri. Adıyaman Üniversitesi Sosyal Bilimler Enstitüsü Dergisi, (27), 891-925.

Sağlam Arslan, A. (2016). Didaktiğin antropolojik teorisi. In E. Bingölbali, S. Arslan, İ. Ö. Zembat (Eds.), Matematik Eğitiminde Teoriler (377-392). Pegem A Akademi.

Sevimli, E. (2013). Bilgisayar cebiri sistemi destekli öğretimin farklı düşünme yapısındaki ögrencilerin integral konusundaki temsil dönüşüm süreçlerine etkisi. Yayımlanmamış doktora tezi, Marmara Üniversitesi, İstanbul.

Shenton, A. K. (2004). Strategies for ensuring trust worthiness in qualitative research projects. Education for information, 22(2), 63-75.

Strauss, A., \& Corbin, J. M. (1990). Basics of qualitative research: Grounded theory procedures and techniques. Sage Publications, Inc.

Şahin, S., \& Balkar, B. (2007). Türk dili ve edebiyatı öğrencilerinin tezsiz yüksek lisans programına ilişkin görüşleri. Ege Eğitim Dergisi, 8(1), 89-112.

Tan Şişman, G. (2017). Öğretmen yetiştirme lisans programları ders içeriklerinde "eğitim programı” kavramı. Hacettepe Üniversitesi Eğitim Fakültesi İlkögrretim Online Dergisi, 16(3), 1301-1315.

Taş, İ. D., Kunduroğlu Akar, T., \& Kıroğlu, E. (2017). Sınıf öğretmenliği lisans programının öğretim üyeleri ve öğretmen adaylarının görüşleri doğrultusunda değerlendirilmesi. Journal of Higher Educationand Science, 7(3), 578-592.

Türnüklü, E. B. (2005). Matematik öğretmen adaylarının pedagojik alan bilgileri ile matematik alan bilgileri arasındaki ilişki. Eğitim Araştırmaları Dergisi, 21, 234-247.

Üstüner, M. (2004). Geçmişten günümüze Türk eğitim sisteminde öğretmen yetiştirme ve günümüz sorunları. İnönü Üniversitesi Eğitim Fakültesi Dergisi. https://www.pegem.net/akademi/kongrebildiri_detay.aspx?id=8232

Yenilmez, K. (2011). Matematik öğretmeni adaylarının matematik tarihi dersine ilişkin düşünceleri. Pamukkale Üniversitesi Eğitim Fakültesi Dergisi, 2(30), 79-90.

Yeşilyurt, E. (2019). Eğitim fakültesi lisans programları ders öğrenme çıktılarının kazanımını etkileyen değişkenlerin etkisi ve nedenleri. Uluslararası Sosyal Araştırmalar Dergisi, 12(63), 904-925.

Yıldırım, A., \& Şimşek, H. (2018). Sosyal bilimlerde nitel araştırma yöntemleri (6.baskı) Ankara: Seçkin Yayıncılık. 
Yin, R. K. (2009). Case study research: Design and methods (4th Ed.). Thousand Oaks, CA: Sage

Yüksek Öğretim Kurulu (YÖK), (2006). Türkiye’nin yükseköğretim stratejisi (Taslak Rapor). http://eua.cu.edu.tr/files/turkiyeninyuksekogretimstratejisi.pdf

Yüksek Öğretim Kurulu (YÖK), (2017). Öğretmen yetiştirme ve eğitim fakülteleri (1982-2007).

Online: https://www.yok.gov.tr/kurumsal/idari-birimler/egitim-ogretimdairesi/ogretmen-yetistirme

Yüksek Öğretim Kurulu (YÖK), (2018). Programların güncelleme gerekçeleri, getirdiği yenilikler ve uygulama esaslart. Online: https://www.yok.gov.tr/kurumsal/idaribirimler/egitim-ogretim-dairesi/yeni-ogretmen-yetistirme-lisans-programlari

\section{Summary}

\section{Statement of Problem}

Teachers play a crucial role in the development and progress of countries. Therefore, training qualified teachers are among the primary objectives of many developed countries, and teacher education programs are one of the most important elements towards this purpose (Tan Şişman, 2017). Grossman and Sands (2008), in teacher training programs achieved many things in Turkey stating that they are not yet sufficient. The teacher training program was rearranged in the focus of the changing needs and demands in society and the research results on the current program (YÖK, 2018).

In this direction, this study focuses on the change in the elementary mathematics teacher undergraduate program, which was first established in 1998 in our country and is now included in many universities' education faculties. This is because content knowledge content reflects a transformation of science faculties in the first years of the program and the education of subject knowledge is given a very limited level. In addition, with the change in 2018, the prevalence of a contrary understanding in the courses and contents of the program led the study to focus on the elementary mathematics teacher undergraduate program. In this regard, the aim of this study is to evaluate the elementary mathematics teacher undergraduate program, which started to be implemented as of the 2018-2019 academic year, in line with the opinions of the instructors

\section{Method}

The participants of the study, in which a qualitative research approach was adopted and designed with a holistic single case study design, are 12 lecturers working in the department of 
mathematics education at a state university in the Eastern Anatolia Region. In the study, the researchers used a semi-structured interview form as the data collection tool, and the descriptive analysis technique was used in the analysis of the data. The coding made by the researchers was reached with an inductive analysis since there was no conceptual structure to guide the coding (Strauss and Corbin, 1990). The interviews made with the lecturers in the study were recorded with a tape recorder, and the credibility of the study was ensured by thoroughly examining and storing.

\section{Findings and Discussions}

The findings were presented under the themes of opinions about the courses, opinions about the problems that may be experienced and opinions about the program's adequacy.

In the findings of the closed courses, both positive and negative opinions were expressed. The views of all participants were positive in the findings of the newly opened courses. In the results of the elective courses, it was seen that most of the participants found it positive in terms of providing flexibility in the program. In the study, negative opinions were expressed towards the field knowledge courses based on the credits of the courses related to the contents of the courses, and positive opinions were expressed in terms of other courses. It was stated that the renewed program was generally found positive in terms of the suitability of the courses to the class level.

In the findings of the problems in the institutional dimension, it was emphasized that the problem of the lack/excess of lecturers in universities might be experienced. In the results of the problems in the material dimension, the views that there is a lack of resources for new courses and that there are no special classes for teaching courses. In the findings obtained about the student-sized problems, it has been expressed that the students who take the lesson from below experience confusion, the program should be reconciled with KPSS, and insecurity occurs.

Most of the participants in the study stated that the renewed program was sufficient for the teaching profession. On the other hand, most of the participants in this study did not find the renewed program enough to integrate technology into education. In addition, different opinions emerged about the program's adequacy in terms of learning and teaching mathematics.

\section{Conclusion and Recommendations}


Results achieved: There are opposite views about the courses closed in the renewed program; the appropriateness of newly opened courses, elective courses, and courses to the grade level is generally seen as positive; the credits and contents of the courses are seen negatively in terms of field knowledge courses; that many problems in institutional, student and material dimensions are experienced / can be experienced; the program is found sufficient in terms of the teaching profession; most of the participants indicate that the program has some shortcomings in terms of the integration of technology into education and the ability to learn and teach mathematics. The realization of the results here can be monitored with longer longitudinal studies. In addition, instead of lecturing in the lessons, the lecturers can take advantage of new technologies and mathematical programs to serve as an example to prospective teachers. 